\title{
Measuring Parental Behavior towards Children's Use of Media and Screen-Devices: The Development and Psychometrical Properties of a Media Parenting Scale for Parents of School-Aged Children
}

\author{
Kateřina Lukavská 1,2,3,*, Jaroslav Vacek ${ }^{1,2}{ }^{\text {, Ondřej Hrabec }}{ }^{3} \mathbb{D}$, Michal Božík ${ }^{3,4}$, Michaela Slussareff 5 , \\ Martina Píšová ${ }^{3}$, David Kocourek ${ }^{3}$, Lucie Svobodová ${ }^{3}$ and Roman Gabrhelík ${ }^{1,2} \mathbb{D}$ \\ 1 Department of Addictology, General University Hospital in Prague, 12000 Prague, Czech Republic; \\ jaroslav.vacek@lf1.cuni.cz (J.V.); roman.gabrhelik@lf1.cuni.cz (R.G.) \\ 2 Department of Addictology, First Faculty of Medicine, Charles University, 12000 Prague, Czech Republic \\ 3 Department of Psychology, Faculty of Education, Charles University, 11000 Prague, Czech Republic; \\ ondrej.hrabec@pedf.cuni.cz (O.H.); michal.bozik@vudpap.sk (M.B.); martinapisova3@gmail.com (M.P.); \\ d.kocourek92@gmail.com (D.K.); zipkaa1@seznam.cz (L.S.) \\ 4 Research Institute of Child Psychology and Pathopsychology, 83105 Bratislava, Slovakia \\ 5 Institute of Information Studies and Librarianship, Faculty of Arts, Charles University, \\ 11000 Prague, Czech Republic; Michaela.Slussareff@ff.cuni.cz \\ check for \\ updates \\ * Correspondence: katerina.lukavska@lf1.cuni.cz
}

Citation: Lukavská, K.; Vacek, J.; Hrabec, O.; Božík, M.; Slussareff, M.; Píšová, M.; Kocourek, D.; Svobodová, L.; Gabrhelík, R. Measuring Parental Behavior towards Children's Use of Media and Screen-Devices: The Development and Psychometrical Properties of a Media Parenting Scale for Parents of School-Aged Children. Int. J. Environ. Res. Public Health 2021, 18, 9178. https://doi.org/10.3390/ ijerph18179178

Academic Editor: Paul B. Tchounwou

Received: 27 July 2021

Accepted: 27 August 2021

Published: 31 August 2021

Publisher's Note: MDPI stays neutral with regard to jurisdictional claims in published maps and institutional affiliations.

Copyright: (c) 2021 by the authors. Licensee MDPI, Basel, Switzerland. This article is an open access article distributed under the terms and conditions of the Creative Commons Attribution (CC BY) license (https:/ / creativecommons.org/licenses/by/ $4.0 /)$.

\begin{abstract}
Children's excessive screen use is associated with health risks such as obesity, sleep problems, attention problems, and others. The effect of parental regulative efforts focused on screen/media use (media parenting) is currently unclear and difficult to examine given the heterogeneity of measuring tools used for its assessment. We aimed to develop an inventory that would enable reliable and valid measurement of media parenting practices (especially active and restrictive mediation) in parents of primary school children. The inventory builds on existing tools, it is comprehensive, yet easy to use in research setting. The original MEPA-36 (36 items) and revised MEPA-20 (20 items) inventories were examined using data from 341 Czech and Slovak parents of children aged between 6 and 10 years. Psychometrical properties were estimated using confirmatory factor and reliability analyses. Model fit was better for MEPA-20 and similar to other currently available tools. Both active and restrictive mediation subscales demonstrated high internal consistency. The internal consistency of newly constructed risky mediation subscales (risky active, risky restrictive, and over-protective mediation) was low. MEPA-20, especially active and restrictive mediation subscales, can be recommended for research on media parenting in context of screen/media use of school-aged children.
\end{abstract}

Keywords: media parenting; parental mediation; active mediation; restrictive mediation; media use; screens; psychometrics; self-report; inventory; measurement

\section{Introduction}

Children's use of screens has been an important topic of pediatrics, psychology, and other disciplines concerning children's health and well-being since the mass spread of TV. Scholars have analyzed watching TV especially in relation with obesity (TV watching as a form of sedentary behavior) and violence (the possible negative outcomes of aggressive content). Today, we witness a mass spread of other screen devices such as smartphones, tablets, computers, gaming consoles etc. Children can use screens almost anytime, anywhere, and anyhow. As a result, children are spending an increasing amount of time with screens [1]. There is much evidence that the inappropriate use of screens may have serious negative outcomes for children. According to large population-based studies, children's 
overuse of screens was found to be associated with obesity [2], sleep problems [3], higher level of emotional distress, depressive symptoms [4], attention problems [5], and other unfavorable conditions [6]. However, new information and communication technologies bring important benefits and are eminently indispensable, as the COVID-19 pandemic clearly has shown. Finding the balance between healthy and fruitful use and the harmful (over) use of screens is of the essence. Parental regulation of children use of media is very important given the fact that the new modern online media and online communication are nearly impossible to control by governments or by standard regulatory mechanisms [7]. Parenting in general, as a sum of practices and parental behavior toward a child, has been confirmed to affect many forms of adolescent risk or harmful behaviors (e.g., substance use, risky sexual behaviors, delinquency [8]), and also problematic internet use $[9,10]$. However, current evidence indicates that parenting strategies focused on media regulation (media parenting) are not very effective in preventing risky or problematic behaviors related to the use of media/screen-devices in children and adolescents [11-13].

\section{Media Parenting}

The concept of media parenting, often called 'parental mediation' [7], is grounded in media consumption research, which has developed in the context of increasing television consumption in children during the second half of the last century. Despite the fact that there is not one predominant theory on parental mediation, scholars usually distinguish between two related but distinct factors: 'active' and 'restrictive' mediation. Active mediation (AM) originally reflected to what extent parents discussed the content of media with their child [14], but has been broadened to reflect general levels of communication about media and also shared experiences of media use between parent and a child [15]. Restrictive mediation (RM) reflects mostly parental practices of developing and implying regulative rules over child's media use $[7,15,16]$. These two concepts (AM and RM) have been adopted by scholars focusing on new media such as the internet or games [11,13].

Surprisingly, media parenting (MP) has not shown consistent effects either on the intensity of children's media use (i.e., media time) [11] or on the problematic use of modern media [13]. The meta-analysis by Collier et al. (2016) assessed the effect of three separate predictors-restrictive mediation, active mediation, and co-viewing —on media time (predominantly watching TV) and several other adolescent outcomes such as aggression, substance use, and sexual behavior. It seems that there is almost no relationship between media parenting and media use, except for the small but significant positive effect of co-viewing on media time, that was present for both watching TV and for online gaming. No effects were found of restrictive or active mediation on the use of internet or games, but, notably, there are a limited number of studies on modern media (eight studies on internet or gaming and RM, and two studies on internet/gaming and AM) [11]. A systematic literature review by Nielsen et al. (2019) focused on the relationship between media parenting and the problematic use of the internet (PIU) and problematic online gaming (POG). In the case of the relationship between RM and PIU, six studies demonstrated a negative association (i.e., protective effect), three studies showed no effect, and three studies demonstrated a positive association (i.e., promoting) effect of RM on PIU. Even more ambiguous results were obtained for POG-three studies suggested the protective effect, three studies showed no effect, and three studies suggested the promoting effect of restrictive mediation on POG. The results were similar for AM-six studies showed the negative association with PIU (i.e., suggested the protective effect), but four studies showed no effect, and one study showed the positive association (i.e., suggested the promoting effect). Most studies (three from four) on AM and POG found no effect [13]. These results may sound improbable and can even be frustrating - does it really not matter what parents do about their children's use of media?

We believe that the inconclusive results are at least partially caused by methodological issues. We thoroughly analyzed the measurement of media parenting (active and restrictive mediation) and identified various problems. First, studies usually used a child's report 
of parenting practices, which may or may not be very accurate. Second, most studies relied on measures of their own construction with various degree of psychometrical quality. Moreover, currently available measuring instruments usually focused only on one type of screen (e.g., smartphone) or on one type of media (e.g., internet), which may not appropriately reflect the reality of media parenting, which is usually focused rather globally on the "use of screens/all media" [17]. Most importantly, most instruments do not distinguish potentially effective and potentially counter-effective practices; for example, setting clear and appropriate rules specifying a child's screen time may be a good practice of RM, while forcing a child to immediately quit the use of a screen device when a parent feels like child was using it for "too long" seems to be a rather negative example of RM.

Given the lack of quality and properly constructed measures of media parenting, we aimed to develop a comprehensive self-report inventory for parents of school-aged children, that would (1) focus on the use of screen devices/media in general, and (2) clearly distinguish between positive (effective) and negative (counter-effective or potentially harmful) practices of both active and restrictive mediation. This study describes the construction of the scale and presents the results of its pilot testing.

\section{Materials and Methods}

\subsection{Setting and Data Collection}

The target population were parents of children attending the first, second, or third grade of elementary school in Czechia and Slovakia, two middle European countries with common history and many similarities. Parents were recruited via cooperating schools that were instructed to ask all parents of children from the respected grades to participate in the study. Every participant created his own unique participant identification code. These codes were used to ensure that participants will remain anonymous, and the researchers can still pair both parents' answers (if provided) to the same child [18].

Data collection took place during December 2020 and January 2021. It should be noted that in both Czechia and Slovakia, there were various restrictions related to the COVID-19 pandemic in place during this period. Parents were not remunerated for their participation. The participation consisted of completing the online survey, which took approximately $30-40 \mathrm{~min}$.

\subsection{Sample}

In Czechia, 325 parents were recruited via six cooperating schools, which were selected from the Prague region based on convenience (past cooperation with the research team). In Slovakia, 84 parents were recruited via seven cooperating schools, which were selected based on (1) their location to represent various regions (west, middle, and east parts of the country) and (2) the willingness of school principals to distribute the questionnaire battery. Another 35 parents were recruited after direct approach by the researcher, thus bringing the total number of participants to 119 in this semi-convenient sample from Slovakia. In total, 103 participants were excluded: 100 based on missing values (more than $20 \%$ of missing values in the whole survey or any missing values in the part focused on media parenting) and 3 based on not having children in target grades. The final sample consisted of 341 Czech and Slovak parents. The detailed characteristics of the sample are presented in Table 1. 
Table 1. Characteristics of the sample.

\begin{tabular}{|c|c|}
\hline Variable & Frequency \\
\hline Age & $\mathrm{M}=40.3(\mathrm{SD}=4.47)$ \\
\hline \multicolumn{2}{|l|}{ Nationality } \\
\hline Czech & $65.4 \%(n=223)$ \\
\hline Slovak & $34.6 \%(n=118)$ \\
\hline \multicolumn{2}{|l|}{ Gender } \\
\hline Female & $81.1 \%(n=275)$ \\
\hline Male & $18.9 \%(n=64)$ \\
\hline \multicolumn{2}{|l|}{ Education } \\
\hline Less than Highschool & $2.9 \%(n=10)$ \\
\hline Highschool graduate & $26.4 \%(n=90)$ \\
\hline University (BA degree) & $8.8 \%(n=30)$ \\
\hline University (MA degree or higher) & $61.9 \%(n=211)$ \\
\hline \multicolumn{2}{|l|}{ Employment } \\
\hline Unemployed & $5.3 \%(n=18)$ \\
\hline Part-time job & $18.2 \%(n=62)$ \\
\hline Full-time job & $65.1 \%(n=222)$ \\
\hline Other & $11.4 \%(n=39)$ \\
\hline \multicolumn{2}{|l|}{ Residence } \\
\hline Less than 999 inh. & $6.2 \%(n=21)$ \\
\hline 1000-4999 inh. & $12.6 \%(n=43)$ \\
\hline 5000-19,999 inh. & $10.3 \%(n=35)$ \\
\hline 20,000-99,999 inh. & $3.2 \%(n=11)$ \\
\hline More than 100,000 inh. & $67.7 \%(n=231)$ \\
\hline \multicolumn{2}{|l|}{ Family situation } \\
\hline Intact family & $89.1 \%(n=304)$ \\
\hline Single-parent family & $3.8 \%(n=13)$ \\
\hline Completed family & $3.5 \%(n=12)$ \\
\hline Alternating care & $3.2 \%(n=11)$ \\
\hline Other family & $0.3 \%(n=1)$ \\
\hline \multicolumn{2}{|l|}{ Pandemic-related situation } \\
\hline At-home schooling & $46.0 \%(n=156)$ \\
\hline
\end{tabular}

\subsection{Measures}

The survey consisted of socio-demographic questions, a media parenting scale (MEPA - see below), and children's media/screen use. In relation to the COVID-19 pandemic situation, parents were asked whether their child is currently studying in school or distantly from their home.

\subsubsection{Media Parenting Scale for School-Aged Children (MEPA)}

As a first step of MEPA construction, we thoroughly analyzed the literature on media parenting (parental mediation) and also currently available measuring instruments. We identified over ten different instruments (scales) assessing media parenting, but only few of them were used more than once. The most frequently used instrument so far was the one developed by Livingstone and Helsper [7], and the second one developed within the EU Kids Online network [16]. We also analyzed other instruments [17,19-24]; based on this, we identified key facets (for the explanation of facet theory please see [25]) of active mediation (AM) and restrictive mediation (RM) and categories within each facet. Both AM and RM included two facets- "parental (regulative) activity" and "the target of this activity". Categories for each facet are provided in Figure 1. 
ACTIVE MEDIATION (AM)

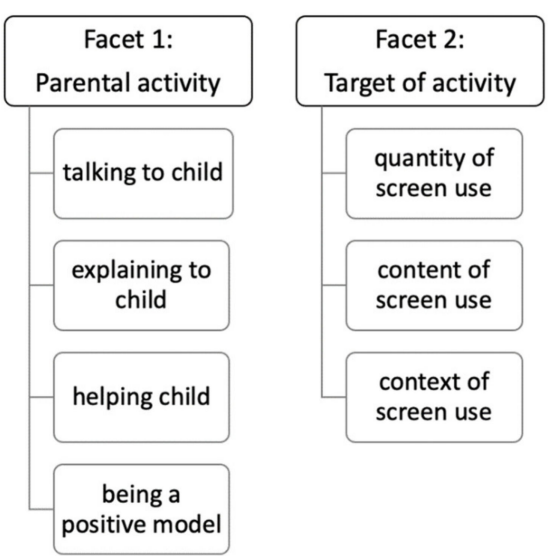

RESTRICTIVE MEDIATION (RM)

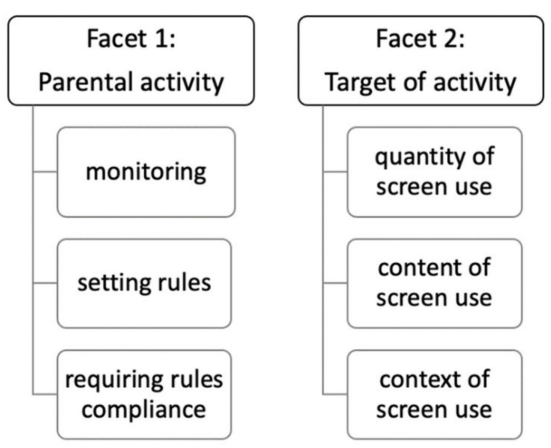

Figure 1. Facets of Active and Restrictive Mediation subscales.

Active and Restrictive Mediation are traditional concepts in media parenting literature. We added Risky Active and Risky Restrictive Mediation subscales in reflection of some previously constructed inventories, which mixed the "good" (presumably effective) and "bad" (presumably ineffective or even harmful) media parenting practices (facets are shown in Figure 2). Distinguishing between positive (effective) and negative (ineffective) practices is not usual within the area of media parenting, but it is well known in the area of general parenting (i.e., distinguishing between "positive" behavior and "negative" psychological control (e.g., love withdrawal, emotional manipulation etc.) [26]).

RISKY ACTIVE MEDIATION (RA)

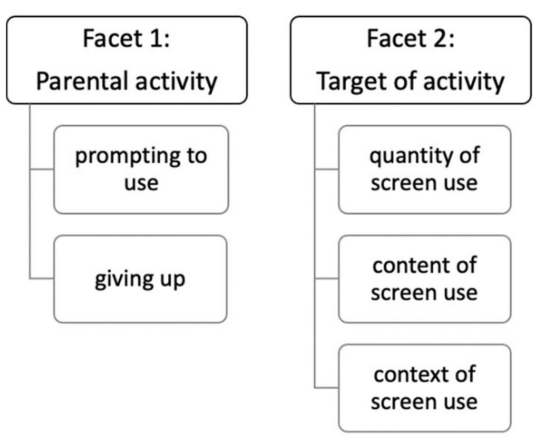

RISKY RESTRICTIVE MEDIATION (RR)

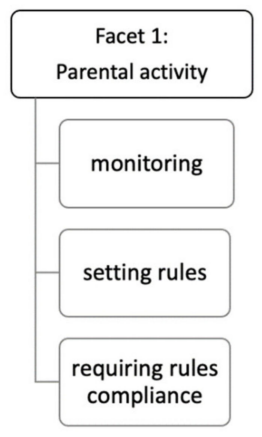

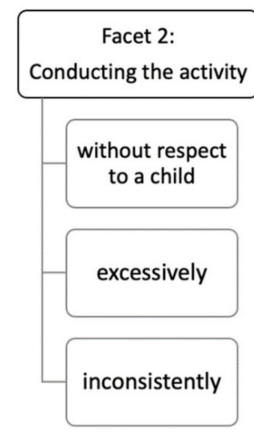

Figure 2. Facets of Risky Active and Risky Restrictive Mediation subscales.

Items were systematically derived by combining categories across facets; for example, the AM item 'I help my child to regulate the amount of time s/he spends using screens.' is a combination of "helping" (facet 1-activity) and "quantity of screen use" (facet 2-target of the activity).

Using this procedure, we generated 36 items (12 items for AM, 9 items for RM, 6 items for RA, and 9 items for RR) constituting the MEPA-36 scale. The scale was constructed originally in Czech, but items were translated into Slovak and English (including backtranslation procedure).

\subsubsection{Scoring of MEPA}

Items are in the form of statements to which respondents (parents) express their level of agreement on a 5 -point Likert scale ( $1=$ totally untrue; $5=$ totally true).

Four scores can be calculated as averages of relevant MEPA-36 items (a full list of items and their respective scales are in Tables A1-A3): 
- Active mediation (AM) reflects to what extent parents communicate with their child about screen use, how much they help him with different aspects of screen use (e.g., finding the right situations to use screens, finding the appropriate content etc.), and to what extent children can use a parent as a model for their own healthy screen use. Generally, the purpose of AM is to teach a child how to use technologies in a healthy and mindful way.

- Restrictive mediation (RM) reflects to what extent parents actively regulate their child's use of screens by monitoring child's screen activities, setting restrictive use, and to what extent parents insist that the child follows these rules. Generally, the purpose of RM is to externally regulate a child's screen use to prevent her/him from overuse or inappropriate use of screens.

- Risky active mediation (RA) reflects to what extent parents voluntarily resign on active parenting of screen use and let the child handle screens by themselves and also to what extent they prompt their child to (over)use technologies. In general, RA practices may lead to excessive and uncontrolled use of screens.

- Risky restrictive mediation (RR) reflects to what extent parents overdo restrictive activities or conduct them in a harmful way; for example, by manipulating the child and by disregarding her/his privacy and self-regulation abilities. In general, parents using RR practices aim to have total control over a child's use of screens and do not hesitate to use any means to reach it.

Similar scoring applies for the revised shortened scale MEPA-20, which consists of three subscales and provides three scores: active mediation, restrictive mediation and overprotective mediation (OP). OP consists of selected RR items (please see Tables A4-A6).

\subsubsection{Child's Screen Use}

Two measures were developed to assess children's screen use: screen time and risky screen use patterns.

Screen time was assessed via a parental report of time spent in the average weekday and time spent in average weekend day on four types of devices with screen: portable screens (smartphone or tablet), gaming console, computer, and television. Parents reported the time their child usually spends at each device using the scale: 0 ( 0 min per day), 1 (less than $30 \mathrm{~min}$ per day), 2 (30 min-1 h per day), 3 (1-2 h per day), 4 ( $2-3 \mathrm{~h}$ per day), 5 ( $3-4 \mathrm{~h}$ per day), and 6 (more than $4 \mathrm{~h}$ per day). To compute the estimated screen time for each child, we used the following procedure. First, we recalculated each response for each device to estimated time in minutes/hours: we used middle values for each interval (i.e., the response " 2 ", from $30 \mathrm{~min}$ to $1 \mathrm{~h}$, we recalculated as $45 \mathrm{~min}$ (respectively $0.75 \mathrm{~h}$ ); the response " 3 ", from 1 to $2 \mathrm{~h}$, we recalculated as $90 \mathrm{~min}$ (respectively $1.5 \mathrm{~h}$ ); the response " 6 ", more than $4 \mathrm{~h}$, was calculated as " $270 \mathrm{~min}$ " (respectively $4.5 \mathrm{~h}$ )). Second, we summed these recalculated estimates to provide the summative estimate of time spent on all devices. Third, we averaged the time spent on all devices during a typical working day and the time spent on all devices during a typical weekend day to estimate average daily screen time.

Risky screen use patterns were measured via seven items in which parents reported how often (never, about once a week, 2 to 3 times a week, every day, or almost every day) their child used a screen device in a way that is considered to be risky or harmful [27-32], namely.

- less than sixty minutes before bedtime

- while travelling

- $\quad$ while eating

- to calm down

- to fall asleep

- $\quad$ as a backdrop for other activities (e.g., playing, homework, etc.)

The inner consistency of scale was rather low (Cronbach $\alpha=0.56$; McDonald $\omega=0.62$ ), which is not unusual for scales with lower number of items and when analyzed using smaller samples. 


\subsection{Statistical Analyses}

First, we performed psychometrical analyses in order to (1) assess the inner consistency of scales using Cronbach $\alpha$ and McDonald's $\omega$, and (2) examine the fit of MEPA using the confirmatory factor analysis. Two models were examined: the originally constructed 4-factor MEPA-36, and a revised and shortened 3-factor MEPA-20.

Second, we examined the relationships among MEPA subfactors and also between MEPA scores and other relevant variables, namely, child's screen use. We presumed that high scores in positive media parenting scales (AM and RM) should-at least to some extent-prevent children from the development of an excessive/problematic use of screens. Contrary, we believed that high scores in risky media parenting scales (RA and RR), which reflect ineffective or even harmful parental behavior, may contribute to the development of the problematic use of screens either directly (in case of RA) or via damaging child-parent relationships, and via parental overprotection that does not allow the child to develop self-regulation of screen use (as in the case of RR). Moreover, we examined the relationship between MEPA and some sociodemographic characteristics of parents (age and gender) and children (age and gender); and also analyzed MEPA factors in relation to COVID-19 restrictions (as nearly half of the sample experienced distant, online schooling at the time of data collection).

\subsection{Ethics}

The study has been approved by an institutional ethical board of the Faculty of Education at Charles University. All participants provided the informed consent for participation.

\section{Results}

\subsection{Socio-Demographic Characteristics of Final Sample}

The age of participating parents ranged from 27 to 53 years $(M=40.3 ; \mathrm{SD}=4.47)$. Parents were mostly female $(81.1 \%)$ with completed university education $(56.9 \%)$. The age of children ranged from 72 months (i.e., 6 years) to 121 months (i.e., 10 years +1 month) $(\mathrm{M}=96.3$ months, $\mathrm{SD}=10.3$ month). Children were $49 \%$ girls. Almost half of the children $(46 \%)$ were distant (home) schooling at the time of data collection due to COVID-19 pandemic restrictions. More sample characteristics are provided in Table 1.

\subsection{Psychometric Properties of MEPA}

First, we assessed the inner consistency of the originally constructed scale (MEPA36; full scale is in Appendix A). Then, we assessed the inner consistency of the revised (shortened) scale MEPA-20 (full scale is in Appendix B).

\subsubsection{MEPA-36}

The inner consistency of Active Mediation (AM) subscale (12 items) was acceptable (Cronbach $\alpha=0.82$, McDonald $\omega=0.83$ ) and only one item (MP17) displayed an item-rest correlation lower than 0.30 (Table 2). The inner consistency of Restrictive Mediation (RM) subscale (9 items) was also acceptable (Cronbach $\alpha=0.75$, McDonald $\omega=0.76$ ) and no item displayed an item-rest correlation lower than 0.30 (Table 2). The inner consistency of Risky Active Mediation (RA) subscale ( 6 items) was low (Cronbach $\alpha=0.58$, McDonald $\omega=0.59$ ) and the majority of items did display weak-to-moderate item-rest correlations (Table 2). Moreover, we found that the means of RA items were very low, which meant that most parents did not report any RA practices. The inner consistency of Risky Restrictive Mediation (RR) subscale (9 items) was very low (Cronbach $\alpha=0.42$, McDonald $\omega=0.48$ ) with the majority of items displaying weak item-rest correlations; one item (MP34) displayed a negative correlation to the rest of the items (Table 2). As opposed to the RA subscale, in the case of RR, we identified a few items with a very high mean value (MP20 and MP30), meaning that parenting strategies expressed in these items were reported very frequently. 
Table 2. MEPA-36 Item Reliability Statistics.

\begin{tabular}{|c|c|c|c|c|c|}
\hline \multirow{2}{*}{ Item } & \multirow{2}{*}{ Mean } & \multirow{2}{*}{ sd } & \multirow{2}{*}{$\begin{array}{l}\text { Item-Rest } \\
\text { Correlation }\end{array}$} & \multicolumn{2}{|c|}{ If Item Dropped } \\
\hline & & & & Cronbach's $\alpha$ & McDonald's $\omega$ \\
\hline \multicolumn{6}{|c|}{ Active Mediation Items: } \\
\hline MP1 & 3.86 & 1.155 & 0.5756 & 0.793 & 0.808 \\
\hline MP2 & 4.09 & 1.061 & 0.6027 & 0.791 & 0.807 \\
\hline $\mathrm{MP} 4$ & 4.19 & 1.057 & 0.45 & 0.805 & 0.82 \\
\hline MP5 & 4.12 & 1.044 & 0.396 & 0.809 & 0.824 \\
\hline MP7 & 4.15 & 0.979 & 0.5979 & 0.793 & 0.805 \\
\hline MP8 & 4.17 & 0.985 & 0.6427 & 0.789 & 0.801 \\
\hline MP10 & 3.71 & 1.106 & 0.3606 & 0.813 & 0.826 \\
\hline MP11 & 4.51 & 0.746 & 0.3685 & 0.811 & 0.826 \\
\hline MP13 & 3.74 & 1.192 & 0.6107 & 0.789 & 0.804 \\
\hline MP14 & 4.16 & 0.925 & 0.5712 & 0.796 & 0.809 \\
\hline MP16 & 3.33 & 1.228 & 0.4398 & 0.807 & 0.82 \\
\hline MP17 & 3.83 & 1.108 & 0.0783 & 0.837 & 0.843 \\
\hline \multicolumn{6}{|c|}{ Restrictive Mediation Items: } \\
\hline MP19 & 4.58 & 0.675 & 0.448 & 0.734 & 0.739 \\
\hline MP21 & 3.96 & 1.108 & 0.492 & 0.72 & 0.732 \\
\hline MP23 & 3.42 & 1.118 & 0.34 & 0.746 & 0.757 \\
\hline MP25 & 4.3 & 0.808 & 0.395 & 0.737 & 0.748 \\
\hline MP27 & 3.83 & 1.11 & 0.49 & 0.721 & 0.732 \\
\hline MP29 & 3.55 & 1.272 & 0.441 & 0.731 & 0.744 \\
\hline MP31 & 3.96 & 0.957 & 0.414 & 0.733 & 0.744 \\
\hline MP33 & 4.06 & 0.989 & 0.503 & 0.72 & 0.731 \\
\hline MP35 & 3.55 & 1.169 & 0.424 & 0.733 & 0.746 \\
\hline \multicolumn{6}{|c|}{ Risky Active Mediation Items: } \\
\hline MP3 & 1.5 & 0.941 & 0.274 & 0.558 & 0.565 \\
\hline MP6 & 1.41 & 0.914 & 0.375 & 0.514 & 0.525 \\
\hline MP9 & 1.36 & 0.866 & 0.382 & 0.513 & 0.523 \\
\hline MP12 & 1.45 & 0.737 & 0.284 & 0.554 & 0.568 \\
\hline MP15 & 2.02 & 1.042 & 0.299 & 0.55 & 0.556 \\
\hline MP18 & 2.12 & 1.032 & 0.321 & 0.539 & 0.545 \\
\hline \multicolumn{6}{|c|}{ Risky Restrictive Mediation Items: } \\
\hline MP20 & 4.08 & 0.929 & 0.3089 & 0.345 & 0.408 \\
\hline MP22 & 2.55 & 1.353 & 0.218 & 0.369 & 0.448 \\
\hline MP24 & 2.92 & 1.126 & 0.2109 & 0.375 & 0.454 \\
\hline MP26 & 2.24 & 1.023 & 0.2148 & 0.375 & 0.446 \\
\hline MP28 & 2.95 & 1.139 & 0.3269 & 0.323 & 0.388 \\
\hline MP30 & 4.09 & 1.007 & 0.2099 & 0.377 & 0.442 \\
\hline MP32 & 2.01 & 0.914 & 0.1457 & 0.401 & 0.484 \\
\hline MP34 & 2.26 & 1.046 & -0.1008 & 0.489 & 0.537 \\
\hline MP36 & 2.44 & 1.397 & 0.0746 & 0.443 & 0.499 \\
\hline
\end{tabular}

\subsubsection{MEPA-20}

As the second step, we assessed the internal consistency of the revised scale MEPA-20. The revised version was developed to (a) shorten the scale to be better suited for the research use and more respondent-friendly, and (b) to address the suboptimal reliability measures of Risky Active and Risky Restrictive mediation subscales. MEPA-20 consists of 20 items divided into three subscales (active mediation, 8 items; restrictive mediation, 8 items; over-protective mediation (composed of selected Risky Restrictive Mediation items, 4 items). The Risky Active Mediation items were removed as it has been found that they were not relevant for media parenting of children in the target age.

The inner consistency of Active Mediation (AM) subscale (8 items) was acceptable (Cronbach $\alpha=0.77$, McDonald $\omega=0.78$ ) and no item displayed an item-rest correlation lower than 0.30 (Table 3). The inner consistency of Restrictive Mediation (RM) subscale (8 items) was acceptable (Cronbach $\alpha=0.73$, McDonald $\omega=0.74$ ) and no item displayed 
an item-rest correlation lower than 0.30 (Table 3). The inner consistency of Over-protective Mediation (OP) scale (4 items) was low (Cronbach $\alpha=0.49$, McDonald $\omega=0.52$ ), which is quite usual in short scales. Two items displayed an item-rest correlation lower than 0.30 (Table 3).

Table 3. MEPA-20 Items Reliability Statistics.

\begin{tabular}{cccccc}
\hline Item & Mean & sd & $\begin{array}{c}\text { Item-Rest } \\
\text { Correlation }\end{array}$ & \multicolumn{2}{c}{$\begin{array}{c}\text { If Item Dropped } \\
\text { Cronbach's } \alpha\end{array}$} \\
& \multicolumn{5}{c}{ McDonald's $\omega$} \\
\hline MP1 & 3.86 & 1.155 & 0.485 & 0.743 & 0.756 \\
MP2 & 4.12 & 1.044 & 0.32 & 0.77 & 0.781 \\
MP3 & 4.17 & 0.985 & 0.608 & 0.723 & 0.735 \\
MP4 & 3.71 & 1.106 & 0.347 & 0.767 & 0.777 \\
MP6 & 4.51 & 0.746 & 0.365 & 0.762 & 0.776 \\
MP7 & 3.74 & 1.192 & 0.637 & 0.713 & 0.727 \\
MP8 & 4.16 & 0.925 & 0.585 & 0.729 & 0.737 \\
MP9 & 3.33 & 1.228 & 0.46 & 0.749 & 0.762 \\
MP11 & 3.96 & 1.108 & 0.47 & 0.698 & 0.705 \\
MP12 & 3.42 & 1.118 & 0.327 & 0.727 & 0.734 \\
MP13 & 4.3 & 0.808 & 0.373 & 0.718 & 0.724 \\
MP14 & 3.83 & 1.11 & 0.488 & 0.694 & 0.698 \\
MP16 & 3.55 & 1.272 & 0.446 & 0.704 & 0.713 \\
MP17 & 3.96 & 0.957 & 0.41 & 0.71 & 0.715 \\
MP18 & 4.06 & 0.989 & 0.494 & 0.695 & 0.7 \\
MP19 & 3.55 & 1.169 & 0.427 & 0.707 & 0.716 \\
MP5 & 2.55 & 1.35 & 0.221 & 0.495 & 0.532 \\
MP10 & 2.92 & 1.13 & 0.235 & 0.464 & 0.584 \\
MP15 & 2.24 & 1.02 & 0.306 & 0.406 & 0.539 \\
MP20 & 2.95 & 1.14 & 0.406 & 0.305 & 0.391 \\
\hline
\end{tabular}

\subsection{Factor Structure of MEPA}

We assessed the model fit of two scales: (1) the original scale (MEPA-36) with four subscales and 36 items as described above, and (2) the revised scale (MEPA-20) with three subscales and 20 items.

Confirmatory factor analysis showed that the examined models differed in the model fit measures (Table 4). The better fit was found for MEPA-20. For MEPA-20, the ratio between $x^{2}$ and degrees of freedom was 3.35, which was in the acceptable range (lower than 5.0) [33]. CFI and TLI values, which should be close to 1.0 or at least exceed 0.9 , were found to be low for both examined models, but higher for MEPA-20. RMSEA values were found to be out of acceptable range- they should be lower than 0.07 [33]. On the other hand, in the case of MEPA-20, all items displayed significant loadings to their respective factors $(p<0.001)$. In the case of MEPA-36, there were three exceptions to this (items MP17, MP32, and MP36).

Table 4. Model Fit Measures.

\begin{tabular}{cccccc}
\hline & $\chi^{2}$ & df & CFI & TLI & RMSEA (90\% CI) \\
\hline MEPA-36 & 1730 & 588 & 0.644 & 0.619 & $0.076(0.071-0.080)$ \\
MEPA-20 & 560 & 167 & 0.758 & 0.724 & $0.083(0.076-0.091)$ \\
\hline
\end{tabular}

Note. $\chi^{2}=\chi^{2}$ after Satorra-Bentler correction; $\mathrm{df}$, degrees of freedom; CFI, Comparative Fit Index; TLI, TuckerLewis Index; RMSEA, Root Mean Square Error of Approximation; CI, Confidence Interval.

\subsection{Score Distribution and Relationships between Variables}

We found that mean values for Active and Restrictive Mediation (as measured by MEPA-20) were relatively high (almost 4 in a 1-to-5 response scale)—see Table 5 . This 
suggested that parents reported the frequent use of media parenting practices (both active and restrictive ones). Contrary, over-protective practices were found less often. As for screen use measures, the estimated average screen time was relatively high for children of the target age (more than $3 \mathrm{~h}$ per day); however, this may be caused by restrictions related to the pandemic situation, which affected both the schooling (children were studying distantly from their homes, usually via online classrooms) and leisure activities.

Table 5. Means, Standard Deviations, and Pearson Correlation Coefficients for MEPA-20 Scores, Screen Time, and Risky Screen Use Patterns.

\begin{tabular}{|c|c|c|c|c|c|c|c|c|c|}
\hline & \multirow{2}{*}{ Variables } & \multirow{2}{*}{ Mean } & \multirow{2}{*}{ SD } & \multicolumn{6}{|c|}{ Pearson Correlation Coefficient } \\
\hline & & & & 1. & & 2. & & 3. & 4. \\
\hline 1. & Active Mediation & 3.90 & 0.74 & & & & & & \\
\hline 2. & $\begin{array}{l}\text { Restrictive } \\
\text { Mediation }\end{array}$ & 3.87 & 0.64 & 0.526 & $* * *$ & & & & \\
\hline 3. & $\begin{array}{l}\text { Over-protective } \\
\text { Mediation }\end{array}$ & 2.66 & 0.73 & 0.353 & $* * *$ & 0.435 & $* * *$ & & \\
\hline 4. & Screen time & 3.37 & 2.03 & 0.023 & & -0.193 & $* * *$ & -0.044 & \\
\hline 5. & $\begin{array}{l}\text { Risky screen use } \\
\text { patterns }\end{array}$ & 0.76 & 0.44 & 0.016 & & -0.208 & $* * *$ & $-0.129 *$ & $0.456 * * *$ \\
\hline
\end{tabular}

As the next step, we examined the relationships between MEPA-20 scores and other relevant variables, namely, the child's screen use measures: screen time and risky screen use patterns; results are presented in Table 5 . We found significant positive and moderately strong associations among all MEPA scores (Active Mediation, Restrictive Mediation and Over-protective Mediation). The significant negative association was found between child's screen use measures (screen time and risky screen use patterns) and Restrictive Mediation. Two screen use measures were positively and moderately associated with each other. Overprotective Mediation was weakly negatively associated with risky screen use patterns but not with screen time. We found close to zero associations between screen use and Active Mediation.

We also examined the relationships between MEPA and the sociodemographic characteristics of parents and children. We did not find any significant association between MEPA and the age of a parent or the age of a child, except for a small positive association between Active Mediation and child's age (Pearson $r=0.13, p=0.02$ ). We found no differences in MEPA based on the child's gender ( $p^{\prime}$ s between 0.50 and 0.85 ; Cohen $d^{\prime} \mathrm{s}<0.1$ ), but we found differences in MEPA based on the parent's gender (i.e., between mothers $(\mathrm{N}=275)$ and fathers $(\mathrm{N}=64))$. Mothers displayed significantly higher scores in Active Mediation $(\mathrm{MD}=0.21, p=0.02$, and Cohen $d=0.33)$, Restrictive Mediation $(\mathrm{MD}=0.18, p=0.04$, and Cohen $d=0.29$ ), and Over-protective Mediation ( $\mathrm{MD}=0.22, p=0.02$, and Cohen $d=0.32$ ).

Finally, we assessed the effect of distant schooling conditions on MEPA factors and other variables. We found no significant differences in MEPA between a distant (online) schooling group and a regular schooling group ( $p$ 's between 0.26 and 0.92; Cohen $d^{\prime}$ s between 0.01 and 0.13 ). However, we found differences between these two groups in screen use. The distant schooling group reported much higher daily screen time compared to the regular schooling group ( $\mathrm{MD}=1.53 \mathrm{~h}, p<0.001$, and Cohen $d=0.81$ ) and also slightly higher risky screen use patterns $(\mathrm{MD}=0.12, p=0.013$, and Cohen $d=0.27)$.

\section{Discussion}

In the field of media parenting, most measurement tools are self-generated for the purpose of one or a few studies. The construction and psychometrical quality of most such instruments is unknown [13]. Our aim was to develop a media parenting scale that would reflect current conceptualizations in the field, and, at the same time, would overcome most common problems of currently existing scales (e.g., mixing good and bad practices, focusing on only one device or one activity, and a lack of balance between active and 
restrictive approaches). Moreover, we aimed specifically for assessing practices of parents of primary school children (aged 6 to 10 years). Our scale (MEPA) has been constructed using the theory of facets [25]; the facets were derived from existing conceptualizations and measuring tools. The scale distinguished between active and restrictive approaches toward a child's media/screen use and also between presumably positive (mediation) and potentially harmful practices (risky/over-protective mediation). The scale focuses on the use of screen-devices/media in general (rather than, for example, on gaming, the internet, or smartphone), which we believe reflects the way parents regulate screen-devices/media use in younger children-parents usually do not distinguish between various devices or activities but rather create regulative rules or guidelines for screen use generally [18].

Two scales were examined: the MEPA-36 with four subscales and 36 items and the MEPA-20 with three subscales and 20 items. The internal consistency was found to be acceptable in the case of the Active Mediation and Restrictive Mediation subscales both in MEPA-36 and MEPA-20. The inner consistency of subscales assessing the risky mediation practices (Risky Active Mediation and Risky Restrictive Mediation in case of MEPA-36 and Over-protective Mediation in case of MEPA-20) was found to be low, and these subscales need further testing. MEPA-20 displayed a better fit to the data compared to MEPA-36; however, most indices of model fit were out of recommended ranges for both MEPA-20 and MEPA-36. On the other hand, in the case of MEPA-20, all items displayed significant $(p<0.001)$ loadings to their respective subscale. Psychometrical properties of MEPA scale are comparable with those reported for currently existing media parenting scales for which psychometrical properties were published $[19,23]$. The lower model fit could be partially caused by the timing of data collection-almost half of participants provided data in the unprecedented situation of schools' lockdown/family quarantine, related to the COVID19 pandemic. We found no significant differences in reported media parenting practices (MEPA factors) between these participants and participants whose children attended school as usual. However, we found significant differences in the reported children's screen use between these two groups. Further studies are needed to examine the model fit of MEPA.

We presumed that MEPA would be associated with a child's screen use. We analyzed two screen use measures: screen time-a parental report of the summative time a child usually spends with all screen-based devices per day, and risky screen use patterns-a parental report of the frequency of screen use patterns that are considered to be harmful (e.g., using screens before sleeping or during meals). Restrictive Mediation was significantly and negatively associated with both screen use measures, but Active Mediation was not; this is in line with previous studies [11,13]. MEPA scores were not significantly associated with sociodemographic characteristics except for parental gender-mothers scored significantly higher than fathers in all three MEPA-20 subscales (Active Mediation, Restrictive Mediation, and Over-protective Mediation).

As the prevalence of screen-related problems in children is growing, the adequate response of the public health sector is necessary to empower their prevention and treatment. The family-based prevention of children's problematic screen/media use is crucial because it is difficult to regulate daily screen use at the level of schools and other institutions [7]. While effective school-based prevention interventions addressing substance use are available [34-36], evidence-based interventions addressing screen/media use are lacking [37], and the ability of schools to address these risks is limited [38]. The first step to improve family-based prevention is to identify effective media parenting practices; this is only possible with appropriate instruments assessing these practices. Our study provided an easy-to-use and reliable scale for assessment of the media parenting practices of the parents of children aged 6 to 10 years. Most importantly, the scale enables assessment of parenting practices aimed at screen/media use in general (not only in the use of one individual screen device (e.g., smartphone) or one individual medium (e.g., games)). To the best of our knowledge, such a scale was missing for this age group. In addition, MEPA-20 assesses not only traditional concepts of active and restrictive mediation, but also overprotective mediation, which may be effective in the short term (when children are young), 
but problematic (counter-effective) in the long term, because it may prevent children from practicing self-regulation of their screen/media use.

The study has additional strengths, and also some limitations, worth noting. The main limitations are related to sampling. The sample size was rather small, and semi-convenient sampling was used. The study was designed as a feasibility study for a large project, in which the representative national samples will be used. Moreover, the survey was rather extensive, taking approximately $30-40 \mathrm{~min}$ to complete; this may have negatively affected the response rate. The above mentioned resulted in an unbalanced sample composition, consisting predominantly of well-educated female participants living in large cities. It is necessary to bear this limitation in mind when using study findings on the extent of media parenting practices and/or children's screen use. Also, data was collected during COVID19 pandemic, which may have influenced the screen use patterns in children. However, the focus of the study was not on the screen use but the media parenting practices, which did not seem to be affected by the pandemic situation. Finally, we did not use another previously published instrument for measuring media parenting alongside the MEPA, which meant we could not provide data on the congruent validity of MEPA. However, analysis of the existing instruments was the first step in developing the MEPA, and we believe that the MEPA reflected the key components of Active and Restrictive mediation well. As for risky mediation/over-protective mediation, we did not identify any previously published instruments that would explicitly measure these concepts.

\section{Conclusions}

The newly constructed scale MEPA is a reliable instrument, which can be used for assessing parenting practices related to the screen/media use (media parenting) of elementary school children (aged 6 to 10 years). The MEPA integrated previously constructed scales measuring media parenting and brought important distinctions between effective and potentially problematic (counter-effective) practices (i.e., over-protective mediation). This study may inform researchers designing studies on a broad range of screen/media activities in children (i.e., media/screen use in general, internet use, social networking, gaming, smartphone use etc.). Such studies are needed to identify effective media parenting strategies that may help parents and prevention professionals address children's problematic screen use.

Author Contributions: Conceptualization, K.L., O.H., and J.V.; methodology, K.L.; formal analysis, K.L.; resources, M.P., D.K., L.S., and M.B.; data curation, M.S. and K.L.; writing-original draft preparation, K.L. and R.G.; writing-review and editing, K.L., O.H., M.B., J.V., M.S., D.K., L.S., and R.G.; supervision, R.G.; project administration, M.P., M.S., and M.B.; funding acquisition, R.G. and K.L. All authors have read and agreed to the published version of the manuscript.

Funding: This research was funded by the Czech Science Foundation (grant number 21-31474S) and by Charles University (grant number Progres Q06).

Institutional Review Board Statement: The study was conducted according to the guidelines of the Declaration of Helsinki, and approved by the Ethics Committee of the Faculty of Education at Charles University, Prague, Czech Republic (11/11 2020).

Informed Consent Statement: Informed consent was obtained from all subjects involved in the study.

Data Availability Statement: Data for this study are available at https:/ / osf.io/8nec4/ (accessed on 27 July 2021).

Conflicts of Interest: The authors declare no conflict of interest. 


\section{Appendix A}

Table A1. MEPA-36: English Version.

\begin{tabular}{|c|c|c|c|c|c|c|c|}
\hline $\begin{array}{l}\text { Item } \\
\text { Code }\end{array}$ & Subscale & Item & & & & & \\
\hline MP1 & $\mathrm{AM}$ & $\begin{array}{l}\text { I chat with my child about time that } \mathrm{s} / \text { he } \\
\text { spends using screens. }\end{array}$ & 1 & 2 & 3 & 4 & 5 \\
\hline MP2 & $\mathrm{AM}$ & $\begin{array}{l}\text { I explain to my child how much time s/he can } \\
\text { spend using screens. }\end{array}$ & 1 & 2 & 3 & 4 & 5 \\
\hline MP3 & RA & $\begin{array}{l}\text { I do not interfere with my child's use of screens, } \\
\text { because s/he knows best how to manage it. }\end{array}$ & 1 & 2 & 3 & 4 & 5 \\
\hline MP4 & $\mathrm{AM}$ & $\begin{array}{l}\text { I help my child to regulate the amount of time } \\
\text { s/he spends using screens. }\end{array}$ & 1 & 2 & 3 & 4 & 5 \\
\hline MP5 & $\mathrm{AM}$ & $\begin{array}{l}\text { My child sees that I am able to regulate my } \\
\text { screen time. }\end{array}$ & 1 & 2 & 3 & 4 & 5 \\
\hline MP6 & RA & $\begin{array}{l}\text { I let my child use screens at will, because "what } \\
\text { doesn't kill you, makes you stronger". }\end{array}$ & 1 & 2 & 3 & 4 & 5 \\
\hline MP7 & $\mathrm{AM}$ & $\begin{array}{l}\text { I chat with my child about the content s/he } \\
\text { consumes through screens (e.g., what videos } \\
\text { s/he watches, games s/he plays, apps s/he } \\
\text { uses, websites, texts, and pictures). }\end{array}$ & 1 & 2 & 3 & 4 & 5 \\
\hline MP8 & AM & $\begin{array}{l}\text { I explain to my child which content is suitable } \\
\text { for her/him (e.g., which videos, games, apps, } \\
\text { websites, texts, and pictures) }\end{array}$ & 1 & 2 & 3 & 4 & 5 \\
\hline MP9 & RA & $\begin{array}{c}\text { I convince my child that using screens is } \\
\text { risk-free. }\end{array}$ & 1 & 2 & 3 & 4 & 5 \\
\hline MP10 & $\mathrm{AM}$ & $\begin{array}{l}\text { I help my child to find suitable content (e.g., } \\
\text { videos, games, apps, websites, texts, and } \\
\text { pictures) }\end{array}$ & 1 & 2 & 3 & 4 & 5 \\
\hline MP11 & $\mathrm{AM}$ & $\begin{array}{c}\text { In front of my child, I consume only such } \\
\text { content (e.g., videos, games, apps, websites, } \\
\text { texts, and pictures) that is also suitable for } \\
\text { him/her. }\end{array}$ & 1 & 2 & 3 & 4 & 5 \\
\hline MP12 & RA & $\begin{array}{l}\text { I prompt my child to use screens in excess (more } \\
\text { than usual) if s/he needs to be entertained or } \\
\text { calmed down. }\end{array}$ & 1 & 2 & 3 & 4 & 5 \\
\hline MP13 & $\mathrm{AM}$ & $\begin{array}{l}\text { I chat with my child about how s/he uses } \\
\text { screens (e.g., before going to bed, during meals, } \\
\text { and during studying). }\end{array}$ & 1 & 2 & 3 & 4 & 5 \\
\hline MP14 & $\mathrm{AM}$ & $\begin{array}{l}\text { I explain to my child in what situations the use } \\
\text { of screens is in/appropriate. }\end{array}$ & 1 & 2 & 3 & 4 & 5 \\
\hline MP15 & RA & $\begin{array}{l}\text { I prompt or let my child to use screens in excess } \\
\text { (more than usual) if it is convenient for me (e.g., } \\
\text { I need to concentrate on my work). }\end{array}$ & 1 & 2 & 3 & 4 & 5 \\
\hline MP16 & $\mathrm{AM}$ & $\begin{array}{l}\text { I help my child to find suitable situations for } \\
\text { watching/using screens. }\end{array}$ & 1 & 2 & 3 & 4 & 5 \\
\hline $\mathrm{MP} 17^{*}$ & $\mathrm{AM}$ & $\begin{array}{l}\text { My child sees that I use screens even when } \\
\text { inappropriate (e.g., during meals). }\end{array}$ & 1 & 2 & 3 & 4 & 5 \\
\hline
\end{tabular}


Table A1. Cont.

\begin{tabular}{|c|c|c|c|c|c|c|c|}
\hline \multirow{2}{*}{$\begin{array}{l}\text { Item } \\
\text { Code } \\
\text { MP18 }\end{array}$} & \multirow{2}{*}{$\begin{array}{c}\text { Subscale } \\
\text { RA }\end{array}$} & \multirow{2}{*}{$\begin{array}{c}\text { Item } \\
\text { I persuade my child to use screens } \\
\text { (technologies) to keep up with times. }\end{array}$} & \multicolumn{5}{|c|}{ Response $^{1}$} \\
\hline & & & 1 & 2 & 3 & 4 & 5 \\
\hline MP19 & $\mathrm{RM}$ & $\begin{array}{l}\text { I notice how much time my child spends using } \\
\text { screens. }\end{array}$ & 1 & 2 & 3 & 4 & 5 \\
\hline MP20 & $\mathrm{RR}$ & $\begin{array}{l}\text { I am the one who sets rules, my child is only } \\
\text { supposed to obey them. }\end{array}$ & 1 & 2 & 3 & 4 & 5 \\
\hline MP21 & $\mathrm{RM}$ & We have agreed rules about screen time. & 1 & 2 & 3 & 4 & 5 \\
\hline MP22 & $\mathrm{RR}$ & $\begin{array}{c}\text { I secretly check my child's screen activities } \\
\text { (when and what my child was watching or what } \\
\text { apps s/he was using). }\end{array}$ & 1 & 2 & 3 & 4 & 5 \\
\hline MP23 & $\mathrm{RM}$ & $\begin{array}{c}\text { I do not let my child use screens longer than } \\
\text { agreed. }\end{array}$ & 1 & 2 & 3 & 4 & 5 \\
\hline MP24 & $\mathrm{RR}$ & $\begin{array}{l}\text { I let my child know that watching/using } \\
\text { screens is a waste of time. }\end{array}$ & 1 & 2 & 3 & 4 & 5 \\
\hline MP25 & $\mathrm{RM}$ & $\begin{array}{l}\text { I notice what content my child consumes } \\
\text { through screens (e.g., what videos s/he watches, } \\
\text { what games s/he plays, what apps s/he uses, } \\
\text { and what text and pictures). }\end{array}$ & 1 & 2 & 3 & 4 & 5 \\
\hline MP26 & $\mathrm{RR}$ & $\begin{array}{l}\text { In our family, we set rules, which almost never } \\
\text { allow children to use screens for entertainment. }\end{array}$ & 1 & 2 & 3 & 4 & 5 \\
\hline MP27 & $\mathrm{RM}$ & $\begin{array}{l}\text { We have agreed rules about what my child may } \\
\text { and may not watch/do on screens (e.g., which } \\
\text { videos, games, apps, texts, and pictures). }\end{array}$ & 1 & 2 & 3 & 4 & 5 \\
\hline MP28 & $\mathrm{RR}$ & I constantly check my child's screen activities. & 1 & 2 & 3 & 4 & 5 \\
\hline MP29 & $\mathrm{RM}$ & $\begin{array}{c}\text { I do not let my child consume other content } \\
\text { than agreed. }\end{array}$ & 1 & 2 & 3 & 4 & 5 \\
\hline MP30 & $\mathrm{RR}$ & $\begin{array}{l}\text { When my child uses screens differently from } \\
\text { what is allowed, I will immediately go for force } \\
\text { quit. }\end{array}$ & 1 & 2 & 3 & 4 & 5 \\
\hline MP31 & $\mathrm{RM}$ & $\begin{array}{c}\text { I notice in which situations my child watches } \\
\text { and uses screens. }\end{array}$ & 1 & 2 & 3 & 4 & 5 \\
\hline MP32 & $\mathrm{RR}$ & $\begin{array}{l}\text { I change rules about the use of screens at will } \\
\text { according to what is currently most convenient } \\
\text { for me. }\end{array}$ & 1 & 2 & 3 & 4 & 5 \\
\hline MP33 & $\mathrm{RM}$ & $\begin{array}{l}\text { We have rules specifying situations in which my } \\
\text { child is or is not allowed to watch/use screens. }\end{array}$ & 1 & 2 & 3 & 4 & 5 \\
\hline MP34 & $\mathrm{RR}$ & $\begin{array}{l}\text { I monitor my child's screen activities only when } \\
\text { it crosses my mind to do so. }\end{array}$ & 1 & 2 & 3 & 4 & 5 \\
\hline MP35 & $\mathrm{RM}$ & $\begin{array}{l}\text { I do not let my child use screens in other than } \\
\text { agreed situations. }\end{array}$ & 1 & 2 & 3 & 4 & 5 \\
\hline MP36 & $\mathrm{RR}$ & $\begin{array}{l}\text { When my child uses a screen inappropriately, I } \\
\text { sometimes do intervene and sometimes don't. }\end{array}$ & 1 & 2 & 3 & 4 & 5 \\
\hline
\end{tabular}

11 (totally untrue), 2 (rather untrue), 3 (neither true nor untrue), 4 (rather true), and 5 (totally true). ${ }^{*}$ reverse coded item. Scoring instructions: The score of Active Mediation (AM) compute as an average of responses on items MP1, MP2, MP4, MP5, MP7, MP8, MP10, MP11, MP13, MP14, MP16, and MP17. Note that MP17 is reverse coded (i.e., you need to recompute the response as follows: $1=5,2=4,3=3,4=2$, and $5=1$ ). The score of Restrictive Mediation (RM) compute as an average of responses on items MP19, MP21, MP23, MP25, MP27, MP29, MP31, MP33, and MP35. The score of Risky Active Mediation (RA) compute as an average of responses on items MP3, MP6, MP9, MP12, MP15, and MP18. The score of Risky Restrictive Mediation (RR) compute as an average of responses on items MP20, MP22, MP24, MP26, MP28, MP30, MP32, MP34, and MP36. 
Table A2. MEPA-36: Czech Version.

Instrukce: Níže najdete různé výroky, které popisují, jak mohou rodiče přistupovat k dětskému užívání obrazovek. Neexistují správné a špatné odpovědi. Prosíme, ohodnot'te, nakolik každý z výroků platí pro vás a vaše dítě.

\begin{tabular}{|c|c|c|c|c|c|c|c|}
\hline \multirow{2}{*}{$\begin{array}{l}\text { Item } \\
\text { Code } \\
\text { MP1 }\end{array}$} & \multirow{2}{*}{$\begin{array}{l}\text { Subscale } \\
\text { AM }\end{array}$} & \multirow{2}{*}{$\begin{array}{c}\text { Item } \\
\text { S dítětem si povídám o tom, kolik času tráví s } \\
\text { obrazovkami. }\end{array}$} & \multicolumn{5}{|c|}{ Response $^{1}$} \\
\hline & & & 1 & 2 & 3 & 4 & 5 \\
\hline MP2 & $\mathrm{AM}$ & $\begin{array}{l}\text { Dítěti vysvětluji, kolik času může strávit s } \\
\text { obrazovkami. }\end{array}$ & 1 & 2 & 3 & 4 & 5 \\
\hline MP3 & RA & $\begin{array}{l}\text { Nezasahuji dítěti do používání obrazovek, } \\
\text { protože ono samo ví nejlíp, jak si s nimi poradit. }\end{array}$ & 1 & 2 & 3 & 4 & 5 \\
\hline MP4 & $\mathrm{AM}$ & $\begin{array}{c}\text { Pomáhám dítěti hlídat čas strávený s } \\
\text { obrazovkami. }\end{array}$ & 1 & 2 & 3 & 4 & 5 \\
\hline MP5 & $\mathrm{AM}$ & $\begin{array}{l}\text { Dítě vidí, že dokážu kontrolovat dobu, kterou } \\
\text { strávím s obrazovkami. }\end{array}$ & 1 & 2 & 3 & 4 & 5 \\
\hline MP6 & RA & $\begin{array}{l}\text { Dítě nechávám používat obrazovky podle jeho } \\
\text { uvážení ve smyslu přísloví “co tě nezabije, to tě } \\
\text { posílí". }\end{array}$ & 1 & 2 & 3 & 4 & 5 \\
\hline MP7 & $\mathrm{AM}$ & $\begin{array}{l}\text { S dítětem si povídám o tom, co prostřednictvím } \\
\text { obrazovky konzumuje (např. na jaká videa se } \\
\text { dívá, jaké hry hraje, jaké aplikace používá, jaké } \\
\text { webové stránky, jaké články a obrázky). }\end{array}$ & 1 & 2 & 3 & 4 & 5 \\
\hline MP8 & $\mathrm{AM}$ & $\begin{array}{c}\text { Dítěti vysvětluji, jaký obsah je pro něj vhodný } \\
\text { (např. jaká videa, jaké hry, jaké aplikace, jaké } \\
\text { webové stránky, jaké články a obrázky). }\end{array}$ & 1 & 2 & 3 & 4 & 5 \\
\hline MP9 & RA & $\begin{array}{l}\text { Přesvědčuji dítě, že užívání obrazovek je bez } \\
\text { rizika. }\end{array}$ & 1 & 2 & 3 & 4 & 5 \\
\hline MP10 & $\mathrm{AM}$ & $\begin{array}{c}\text { Dítěti pomáhám vyhledávat vhodný obsah } \\
\text { (např. videa, hry, aplikace, webové stránky, } \\
\text { články a obrázky). }\end{array}$ & 1 & 2 & 3 & 4 & 5 \\
\hline MP11 & $\mathrm{AM}$ & $\begin{array}{l}\text { Před dítětem konzumuji pouze takový obsah } \\
\text { (např. videa, hry, aplikace, webové stránky, } \\
\text { články a obrázky), který je pro něj/ni vhodný. }\end{array}$ & 1 & 2 & 3 & 4 & 5 \\
\hline MP12 & RA & $\begin{array}{c}\text { Dítě povzbuzuji k používání obrazovek (i nad } \\
\text { obvyklou míru), když potřebuje zabavit nebo } \\
\text { uklidnit. }\end{array}$ & 1 & 2 & 3 & 4 & 5 \\
\hline MP13 & $\mathrm{AM}$ & $\begin{array}{c}\text { S dítětem si povídám o tom, jakým způsobem } \\
\text { používá obrazovky (např. před spaním, při } \\
\text { učení, při jídle...). }\end{array}$ & 1 & 2 & 3 & 4 & 5 \\
\hline MP14 & $\mathrm{AM}$ & $\begin{array}{l}\text { Dítěti vysvětluji, ve kterých situacích používání } \\
\text { obrazovek je a není vhodné. }\end{array}$ & 1 & 2 & 3 & 4 & 5 \\
\hline MP15 & RA & $\begin{array}{l}\text { Dítě pobízím k použíání obrazovek (i nad } \\
\text { obvyklou míru), pokud je to pro mě výhodné } \\
\text { (např. potřebuji klid na práci). }\end{array}$ & 1 & 2 & 3 & 4 & 5 \\
\hline MP16 & $\mathrm{AM}$ & $\begin{array}{l}\text { Dítěti pomáhám najít vhodné situace, ve } \\
\text { kterých může používat obrazovky. }\end{array}$ & 1 & 2 & 3 & 4 & 5 \\
\hline MP17 * & $\mathrm{AM}$ & $\begin{array}{l}\text { Dítě je svědkem toho, že obrazovky používám i } \\
\text { v nevhodných situacích (např. během jídla). }\end{array}$ & 1 & 2 & 3 & 4 & 5 \\
\hline MP18 & RA & $\begin{array}{l}\text { Dítě povzbuzuji k používání obrazovek } \\
\text { (technologií), aby drželo krok s dobou. }\end{array}$ & 1 & 2 & 3 & 4 & 5 \\
\hline
\end{tabular}


Table A2. Cont.

\begin{tabular}{|c|c|c|c|c|c|c|c|}
\hline \multirow{2}{*}{$\begin{array}{l}\text { Item } \\
\text { Code } \\
\text { MP19 }\end{array}$} & \multirow{2}{*}{$\begin{array}{l}\text { Subscale } \\
\text { RM }\end{array}$} & \multicolumn{2}{|l|}{ Item } & \multicolumn{4}{|c|}{ Response $^{1}$} \\
\hline & & Všímám si, kolik času dítě tráví s obrazovkami. & 1 & 2 & 3 & 4 & 5 \\
\hline MP20 & RR & $\begin{array}{l}\text { Pravidla používání obrazovek určuji já, dítě je } \\
\text { má pouze dodržovat. }\end{array}$ & 1 & 2 & 3 & 4 & 5 \\
\hline MP21 & $\mathrm{RM}$ & $\begin{array}{l}\text { Máme dohodnutá pravidla, kolik času dítě } \\
\text { stráví s obrazovkami. }\end{array}$ & 1 & 2 & 3 & 4 & 5 \\
\hline MP22 & RR & $\begin{array}{l}\text { Tajně kontroluji, co a kdy dítě na obrazovce } \\
\text { sledovalo nebo jaké aplikace používalo. }\end{array}$ & 1 & 2 & 3 & 4 & 5 \\
\hline MP23 & $\mathrm{RM}$ & $\begin{array}{c}\begin{array}{c}\text { Nenechám dítě s obrazovkou déle, než máme } \\
\text { dohodnuto. }\end{array}\end{array}$ & 1 & 2 & 3 & 4 & 5 \\
\hline MP24 & $\mathrm{RR}$ & $\begin{array}{c}\text { Dítěti dávám najevo, že používat obrazovky je } \\
\text { podle mě ztráta času. }\end{array}$ & 1 & 2 & 3 & 4 & 5 \\
\hline MP25 & $\mathrm{RM}$ & $\begin{array}{l}\text { Všímám si toho, co dítě prostřednictvím } \\
\text { obrazovky konzumuje (např. na jaká videa se } \\
\text { dívá, jaké hry hraje, jaké aplikace používá, jaké } \\
\text { články a obrázky). }\end{array}$ & 1 & 2 & 3 & 4 & 5 \\
\hline MP26 & RR & $\begin{array}{l}\text { Pravidla nastavujeme tak, aby dítě nepoužívalo } \\
\text { obrazovky pro zábavu téměř vủbec. }\end{array}$ & 1 & 2 & 3 & 4 & 5 \\
\hline MP27 & $\mathrm{RM}$ & $\begin{array}{l}\text { Máme dohodnutá pravidla, čemu se dítě na } \\
\text { obrazovce smí a nesmí věnovat (kterým hrám, } \\
\text { videím, aplikacím, textům, obrázkům...). }\end{array}$ & 1 & 2 & 3 & 4 & 5 \\
\hline MP28 & RR & $\begin{array}{l}\text { Neustále kontroluji, čemu se dítě na obrazovce } \\
\text { věnuje. }\end{array}$ & 1 & 2 & 3 & 4 & 5 \\
\hline MP29 & $\mathrm{RM}$ & $\begin{array}{l}\text { Nenechám dítě konzumovat jiný obsah než ten, } \\
\text { na kterém jsme se domluvili. }\end{array}$ & 1 & 2 & 3 & 4 & 5 \\
\hline MP30 & $\mathrm{RR}$ & $\begin{array}{l}\text { Kdykoliv mé dítě použivá obrazovku jinak, než } \\
\text { má dovoleno, okamžitě ho donutím, aby } \\
\text { přestalo. }\end{array}$ & 1 & 2 & 3 & 4 & 5 \\
\hline MP31 & $\mathrm{RM}$ & $\begin{array}{l}\text { Všímám si, v jakých situacích dítě sleduje a } \\
\text { použivá obrazovky. }\end{array}$ & 1 & 2 & 3 & 4 & 5 \\
\hline MP32 & RR & $\begin{array}{l}\text { Pravidla měním podle toho, jak se mi to v } \\
\text { aktuální situaci nejvíc hodí. }\end{array}$ & 1 & 2 & 3 & 4 & 5 \\
\hline MP33 & $\mathrm{RM}$ & $\begin{array}{l}\text { Máme pravidla, v jakých situacích dítě smí a } \\
\text { nesmí sledovat a používat obrazovky. }\end{array}$ & 1 & 2 & 3 & 4 & 5 \\
\hline MP34 & RR & $\begin{array}{l}\text { Sleduji, co dítě na obrazovce dělá, jen když si na } \\
\text { to zrovna vzpomenu. }\end{array}$ & 1 & 2 & 3 & 4 & 5 \\
\hline MP35 & $\mathrm{RM}$ & $\begin{array}{l}\text { Nenechám dítě sledovat nebo používat } \\
\text { obrazovky mimo dohodnuté situace. }\end{array}$ & 1 & 2 & 3 & 4 & 5 \\
\hline MP36 & RR & $\begin{array}{l}\text { Pokud dítě používá obrazovky nevhodně, } \\
\text { někdy zasáhnu, jindy ne. }\end{array}$ & 1 & 2 & 3 & 4 & 5 \\
\hline $\begin{array}{l}\text { kódovaná }(\mathrm{t} \\
\text { Mediace }(\mathrm{R} \\
\text { MP33, a MI } \\
\text { MP9, MP12, }\end{array}$ & $\begin{array}{l}\text { 7, MP8, MP } \\
\text { třeba jí pře } \\
\text { vypočtěte ja } \\
\text { Skór Rizik } \\
15 \text {, a MP18. }\end{array}$ & $\begin{array}{l}\text { neplatí), } 3 \text { (tak napůl), } 4 \text { (spíše platí), } 5 \text { (rozhodně platí). * * } \\
\text { kór Aktivní Mediace (AM) vypočtěte jako průměr odpc } \\
\text { 10, MP11, MP13, MP14, MP16, a MP17. Mějte na paměti } \\
\text { počítat následujícím zpưsobem: } 1=5,2=4,3=3,4=2 \text {, } \\
\text { ako průměr odpovědí na položky MP19, MP21, MP23, } \\
\text { ové Aktivní Mediace (RA) vypočtěte jako průměr odpo } \\
\text { Skór Rizikové Restriktivní Mediace (RR) vypočtěte jako } \\
\text { MP28, MP30, MP32, MP34, a MP36. }\end{array}$ & & & & & $\begin{array}{l}\text { ačně } \\
\text { tivní } \\
\text { IP31, } \\
\text { MP6, } \\
\text { ožky }\end{array}$ \\
\hline
\end{tabular}


Table A3. MEPA-36: Slovak version.

Inštrukcia: V tejto časti sú rôzne výroky, ktoré hovoria, ako môžu rodičia pristupovat' k detskému uživaniu obrazoviek.

Neexistujú správne a zlé odpovede. Prosíme, ohodnot'te, nakol'ko každý z výrokov platí pre vás a vaše diet'a.

\begin{tabular}{|c|c|c|c|c|c|c|c|}
\hline \multirow{2}{*}{$\begin{array}{l}\text { Item } \\
\text { Code }\end{array}$} & \multirow{2}{*}{$\begin{array}{c}\text { Subscale } \\
\text { AM }\end{array}$} & \multirow{2}{*}{$\begin{array}{c}\text { Item } \\
\begin{array}{l}\text { S diet'at'om sa rozprávam o tom, kol'ko času } \\
\text { tráví s obrazovkami. }\end{array}\end{array}$} & \multicolumn{5}{|c|}{ Response $^{1}$} \\
\hline & & & 1 & 2 & 3 & 4 & 5 \\
\hline MP2 & $\mathrm{AM}$ & $\begin{array}{l}\text { Diet'at'u vysvetl'ujem, kol'ko času môže strávit' } \\
\text { s obrazovkami. }\end{array}$ & 1 & 2 & 3 & 4 & 5 \\
\hline MP3 & RA & $\begin{array}{l}\text { Nezasahujem diet'at'u do používania } \\
\text { obrazoviek, pretože ono samo vie najlepšie, ako } \\
\text { si s nimi poradit. }\end{array}$ & 1 & 2 & 3 & 4 & 5 \\
\hline MP4 & $\mathrm{AM}$ & $\begin{array}{l}\text { Pomáhám diet'at'u strážit' si čas, strávený s } \\
\text { obrazovkami. }\end{array}$ & 1 & 2 & 3 & 4 & 5 \\
\hline MP5 & $\mathrm{AM}$ & $\begin{array}{l}\text { Diet'a vidí, že dokážem kontrolovat' dobu, } \\
\text { ktorú strávim s obrazovkami. }\end{array}$ & 1 & 2 & 3 & 4 & 5 \\
\hline MP6 & RA & $\begin{array}{c}\text { Diet’a nechávam používat' obrazovky podl'a } \\
\text { jeho uváženia v zmysle príslovia "č́o t’a } \\
\text { nezabije, to t'a posilní“. }\end{array}$ & 1 & 2 & 3 & 4 & 5 \\
\hline MP7 & $\mathrm{AM}$ & $\begin{array}{l}\text { S diet'at'om sa rozprávam o tom, čo } \\
\text { prostredníctvom obrazovky konzumuje (napr. } \\
\text { na aké videa sa pozerá, aké hry hraje, aké } \\
\text { aplikácie používá, aké webové stránky, aké } \\
\text { články a obrázky). }\end{array}$ & 1 & 2 & 3 & 4 & 5 \\
\hline MP8 & $\mathrm{AM}$ & $\begin{array}{c}\text { Diet'at'u vysvetl'ujem, aký obsah je pre neho } \\
\text { vhodný (napr. na aké videá sa pozerá, aké hry } \\
\text { hraje, aké aplikácie použivá, aké webové } \\
\text { stránky, aké články a obrázky). }\end{array}$ & 1 & 2 & 3 & 4 & 5 \\
\hline MP9 & RA & $\begin{array}{c}\text { Presviedčam diet’a, že užívanie obrazoviek je } \\
\text { bez rizika. (Presvedčujem diet'a, že pri } \\
\text { použivaní obrazoviek nehrozí žiadne } \\
\text { nebezpečenstvo) }\end{array}$ & 1 & 2 & 3 & 4 & 5 \\
\hline MP10 & AM & $\begin{array}{l}\text { Diet'at'u pomáhám vyhl'adávat' vhodný obsah } \\
\text { (napr. videá, hry, aplikácie, webové stránky, } \\
\text { články a obrázky). }\end{array}$ & 1 & 2 & 3 & 4 & 5 \\
\hline MP11 & AM & $\begin{array}{l}\text { Pred diet'at'om konzumujem iba taký obsah } \\
\text { (napr. videá, hry, aplikácie, webové stránky, } \\
\text { články a obrázky), ktorý je pre neho vhodný. }\end{array}$ & 1 & 2 & 3 & 4 & 5 \\
\hline MP12 & RA & $\begin{array}{c}\text { Diet'a povzbudzujem k používaniu obrazoviek } \\
\text { (i nad obvyklú mieru), ked' ho potrebujem } \\
\text { zabavit' alebo utišit'. }\end{array}$ & 1 & 2 & 3 & 4 & 5 \\
\hline MP13 & $\mathrm{AM}$ & $\begin{array}{l}\text { S diet'at'om sa rozprávame o tom, akým } \\
\text { spôsobom používa obrazovky (napr. pred } \\
\text { spaním, pri učení, pri jedle...). }\end{array}$ & 1 & 2 & 3 & 4 & 5 \\
\hline MP14 & $\mathrm{AM}$ & $\begin{array}{l}\text { Diet'at'u vysvetl'ujem, v ktorých situáciách je } \\
\text { používanie obrazoviek vhodné a v ktorých nie. }\end{array}$ & 1 & 2 & 3 & 4 & 5 \\
\hline MP15 & RA & $\begin{array}{l}\text { Diet’a povzbudzujem k používaniu obrazoviek } \\
\text { (i nad obvyklú mieru), ak je to pre mňa výhodné } \\
\text { (napr. potrebujem kl'ud na prácu). }\end{array}$ & 1 & 2 & 3 & 4 & 5 \\
\hline MP16 & $\mathrm{AM}$ & $\begin{array}{l}\text { Diet'at'u pomáham nájst' vhodné situácie, v } \\
\text { ktorých môže používat' obrazovky. }\end{array}$ & 1 & 2 & 3 & 4 & 5 \\
\hline $\mathrm{MP} 17^{*}$ & $\mathrm{AM}$ & $\begin{array}{l}\text { Diet'a je svedkom toho, že obrazovky používam } \\
\text { aj v nevhodných situáciách (napr. počas jedla). }\end{array}$ & 1 & 2 & 3 & 4 & 5 \\
\hline
\end{tabular}


Table A3. Cont.

\begin{tabular}{|c|c|c|c|c|c|c|c|}
\hline \multirow{2}{*}{$\begin{array}{l}\text { Item } \\
\text { Code } \\
\text { MP18 }\end{array}$} & \multirow{2}{*}{$\begin{array}{c}\text { Subscale } \\
\text { RA }\end{array}$} & \multirow{2}{*}{$\begin{array}{c}\text { Item } \\
\begin{array}{c}\text { Diet'a povzbudzujem k používaniu obrazoviek } \\
\text { (technológií), aby držalo krok s dobou. }\end{array}\end{array}$} & \multicolumn{5}{|c|}{ Response ${ }^{1}$} \\
\hline & & & 1 & 2 & 3 & 4 & 5 \\
\hline MP19 & $\mathrm{RM}$ & $\begin{array}{l}\text { Všímám si, kol'ko času diet'a trávi s } \\
\text { obrazovkami. }\end{array}$ & 1 & 2 & 3 & 4 & 5 \\
\hline MP20 & $\mathrm{RR}$ & $\begin{array}{c}\text { Pravidlá používania obrazoviek určujem ja, } \\
\text { diet'a ich má iba dodržiavat'. }\end{array}$ & 1 & 2 & 3 & 4 & 5 \\
\hline MP21 & $\mathrm{RM}$ & $\begin{array}{c}\text { Máme dohodnuté pravidlá, kol'ko času má } \\
\text { diet'a strávít' s obrazovkami. }\end{array}$ & 1 & 2 & 3 & 4 & 5 \\
\hline MP22 & $\mathrm{RR}$ & $\begin{array}{c}\text { Tajne kontrolujem, čo a kedy diet’a na } \\
\text { obrazovke sledovalo alebo aké aplikácie } \\
\text { používalo. }\end{array}$ & 1 & 2 & 3 & 4 & 5 \\
\hline MP23 & $\mathrm{RM}$ & $\begin{array}{l}\text { Nenechám diet'a s obrazovkou dlhšie, než } \\
\text { máme dohodnuté. }\end{array}$ & 1 & 2 & 3 & 4 & 5 \\
\hline MP24 & $\mathrm{RR}$ & $\begin{array}{c}\text { Diet'at'u dávam najavo, že používat' obrazovky } \\
\text { je podl'a mňa strata času. }\end{array}$ & 1 & 2 & 3 & 4 & 5 \\
\hline MP25 & RM & $\begin{array}{l}\text { Všímám si to, čo diet’a prostredníctvom } \\
\text { obrazovky konzumuje (napr. na aké videá sa } \\
\text { pozerá, aké hry hrá, aké aplikácie používa, aké } \\
\text { články a obrázky). }\end{array}$ & 1 & 2 & 3 & 4 & 5 \\
\hline MP26 & RR & $\begin{array}{c}\text { Pravidlá nastavujeme tak, aby diet’a } \\
\text { nepoužívalo obrazovky pre zábavu takmer } \\
\text { vôbec. }\end{array}$ & 1 & 2 & 3 & 4 & 5 \\
\hline MP27 & RM & $\begin{array}{l}\text { Máme dohodnuté pravidlá, čomu sa diet’a na } \\
\text { obrazovke smie a nesmie venovat' (ktorým } \\
\text { hrám, videám, aplikáciám, textom, obrázkom...). }\end{array}$ & 1 & 2 & 3 & 4 & 5 \\
\hline MP28 & $\mathrm{RR}$ & $\begin{array}{c}\text { Neustále kontrolujem, čomu sa diet'a na } \\
\text { obrazovke venuje. }\end{array}$ & 1 & 2 & 3 & 4 & 5 \\
\hline MP29 & $\mathrm{RM}$ & $\begin{array}{l}\text { Nenechám diet'a konzumovat' iný obsah než } \\
\text { ten, na ktorom sme sa dohodli. }\end{array}$ & 1 & 2 & 3 & 4 & 5 \\
\hline MP30 & $\mathrm{RR}$ & $\begin{array}{l}\text { Ak diet'a poruší pravidlá, ako má používat' } \\
\text { obrazovku, trvám na tom, aby ju používat' } \\
\text { okamžite prestalo (ihned' zariadenie vypnem } \\
\text { alebo mu ho odeberiem). }\end{array}$ & 1 & 2 & 3 & 4 & 5 \\
\hline MP31 & $\mathrm{RM}$ & $\begin{array}{l}\text { Všímám si, v ktorých situáciách diet’a sleduje a } \\
\text { používa obrazovky. }\end{array}$ & 1 & 2 & 3 & 4 & 5 \\
\hline MP32 & RR & $\begin{array}{l}\text { Pravidlá mením podl'a toho, ako sa mi to v } \\
\text { aktuálnej situácii najviac hodí. }\end{array}$ & 1 & 2 & 3 & 4 & 5 \\
\hline MP33 & $\mathrm{RM}$ & $\begin{array}{l}\text { Máme pravidlá, } \mathrm{v} \text { akých situáciách diet'a smie a } \\
\text { nesmie sledovat' a používat' obrazovky. }\end{array}$ & 1 & 2 & 3 & 4 & 5 \\
\hline MP34 & RR & $\begin{array}{l}\text { Sledujem, čo diet'a na obrazovke robí, iba vtedy, } \\
\text { ked' si na to zrovna spomeniem. }\end{array}$ & 1 & 2 & 3 & 4 & 5 \\
\hline MP35 & $\mathrm{RM}$ & $\begin{array}{l}\text { Nenechám diet'a sledovat' alebo používat' } \\
\text { obrazovky mimo dohodnuté situácie. }\end{array}$ & 1 & 2 & 3 & 4 & 5 \\
\hline MP36 & $\mathrm{RR}$ & $\begin{array}{l}\text { Pokial' diet'a používá obrazovky nevhodne, } \\
\text { niekedy zasiahnem, inokedy nie. }\end{array}$ & 1 & 2 & 3 & 4 & 5 \\
\hline
\end{tabular}

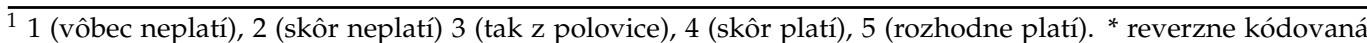
položka. Inštrukcie pre skórovanie: Skóre Aktívna Mediácia (AM) vypočítame ako priemer odpovedí na položky MP1, MP2, MP4, MP5, MP7, MP8, MP10, MP11, MP13, MP14, MP16, a MP17. Majte na pamäti, že položka MP17 je opačne kódovaná (tj. je treba ju prepočítat' následujícím spôsobom: $1=5,2=4,3=3,4=2$, and $5=1$ ) Skóre Reštriktívna Mediácia (RM) vypočítáme ako priemer odpovedí na položky MP19, MP21, MP23, MP25, MP27, MP29, MP31, MP33, a MP35. Skóre Riziková Aktívna Mediácia (RA) vypočítame ako priemer odpovedí na položky MP3, MP6, MP9, MP12, MP15, a MP18. Skóre Riziková Reštriktívna Mediácia (RR) vypočítame ako priemer odpovedí na položky MP20, MP22, MP24, MP26, MP28, MP30, MP32, MP34, a MP36. 


\section{Appendix B}

Table A4. MEPA-20: English Version.

\begin{tabular}{|c|c|c|c|c|c|c|c|}
\hline $\begin{array}{l}\text { Item } \\
\text { Code }\end{array}$ & Subscale & Item & & & & & \\
\hline MP1 & $\mathrm{AM}$ & $\begin{array}{l}\text { I chat with my child about time that } \mathrm{s} / \text { he } \\
\text { spends using screens. }\end{array}$ & 1 & 2 & 3 & 4 & 5 \\
\hline MP2 & $\mathrm{AM}$ & $\begin{array}{l}\text { My child sees that I am able to regulate my } \\
\text { screen time. }\end{array}$ & 1 & 2 & 3 & 4 & 5 \\
\hline MP3 & $\mathrm{AM}$ & $\begin{array}{l}\text { I explain to my child which content is suitable } \\
\text { for her / him (e.g., which videos, games, apps, } \\
\text { websites, texts, and pictures) }\end{array}$ & 1 & 2 & 3 & 4 & 5 \\
\hline MP4 & $\mathrm{AM}$ & $\begin{array}{l}\text { I help my child to find suitable content (e.g., } \\
\text { videos, games, apps, websites, texts and } \\
\text { pictures) }\end{array}$ & 1 & 2 & 3 & 4 & 5 \\
\hline MP5 & $\mathrm{OP}$ & $\begin{array}{c}\text { I secretly check my child's screen activities } \\
\text { (when and what my child was watching or what } \\
\text { apps s/he was using). }\end{array}$ & 1 & 2 & 3 & 4 & 5 \\
\hline MP6 & $\mathrm{AM}$ & $\begin{array}{c}\text { In front of my child, I consume only such } \\
\text { content (e.g., videos, games, apps, websites, } \\
\text { texts, and pictures) that is also suitable for } \\
\text { him/her. }\end{array}$ & 1 & 2 & 3 & 4 & 5 \\
\hline MP7 & $\mathrm{AM}$ & $\begin{array}{l}\text { I chat with my child about how s/he uses } \\
\text { screens (e.g., before going to bed, during meals, } \\
\text { and during studying). }\end{array}$ & 1 & 2 & 3 & 4 & 5 \\
\hline MP8 & $\mathrm{AM}$ & $\begin{array}{l}\text { I explain to my child in what situations the use } \\
\text { of screens is in/appropriate. }\end{array}$ & 1 & 2 & 3 & 4 & 5 \\
\hline MP9 & $\mathrm{AM}$ & $\begin{array}{l}\text { I help my child to find suitable situations for } \\
\text { watching/using screens. }\end{array}$ & 1 & 2 & 3 & 4 & 5 \\
\hline MP10 & $\mathrm{OP}$ & $\begin{array}{l}\text { I let my child know that watching/using } \\
\text { screens is a waste of time. }\end{array}$ & 1 & 2 & 3 & 4 & 5 \\
\hline MP11 & $\mathrm{RM}$ & We have agreed rules about screen time. & 1 & 2 & 3 & 4 & 5 \\
\hline MP12 & $\mathrm{RM}$ & $\begin{array}{c}\text { I do not let my child use screens longer than } \\
\text { agreed. }\end{array}$ & 1 & 2 & 3 & 4 & 5 \\
\hline MP13 & RM & $\begin{array}{c}\text { I notice what content my child consumes } \\
\text { through screens (e.g., what videos s/he watches, } \\
\text { games s/he plays, apps s/he uses, text, and } \\
\text { pictures). }\end{array}$ & 1 & 2 & 3 & 4 & 5 \\
\hline MP14 & $\mathrm{RM}$ & $\begin{array}{l}\text { We have agreed rules about what my child may } \\
\text { and may not watch on/do on screens (e.g., } \\
\text { which videos, games, apps, texts, and pictures). }\end{array}$ & 1 & 2 & 3 & 4 & 5 \\
\hline MP15 & $\mathrm{OP}$ & I constantly check my child's screen activities. & 1 & 2 & 3 & 4 & 5 \\
\hline MP16 & $\mathrm{RM}$ & $\begin{array}{l}\text { I do not let my child consume other content } \\
\text { than agreed. }\end{array}$ & 1 & 2 & 3 & 4 & 5 \\
\hline MP17 & $\mathrm{RM}$ & $\begin{array}{c}\text { I notice in which situations my child watches } \\
\text { and uses screens. }\end{array}$ & 1 & 2 & 3 & 4 & 5 \\
\hline MP18 & RM & $\begin{array}{l}\text { We have rules specifying situations in which my } \\
\text { child is or is not allowed to watch/use screens. }\end{array}$ & 1 & 2 & 3 & 4 & 5 \\
\hline
\end{tabular}


Table A4. Cont.

\begin{tabular}{|c|c|c|c|c|c|c|c|}
\hline \multirow{2}{*}{$\begin{array}{l}\text { Item } \\
\text { Code } \\
\text { MP19 }\end{array}$} & \multirow{2}{*}{$\begin{array}{c}\text { Subscale } \\
\text { RM }\end{array}$} & \multirow{2}{*}{$\begin{array}{l}\text { Item } \\
\text { I do not let my child use screens in other than } \\
\text { agreed situations. }\end{array}$} & \multicolumn{5}{|c|}{ Response $^{1}$} \\
\hline & & & 1 & 2 & 3 & 4 & 5 \\
\hline MP20 & $\mathrm{OP}$ & $\begin{array}{l}\text { In our family, we set rules which almost never } \\
\text { allow children to use screens for entertainment. }\end{array}$ & 1 & 2 & 3 & 4 & 5 \\
\hline
\end{tabular}

Table A5. MEPA-20: Czech version.

Instrukce: Níže najdete různé výroky, které popisují, jak mohou rodiče přistupovat k dětskému užívání obrazovek. Neexistují správné a špatné odpovědi. Prosíme, ohodnot'te, nakolik každý z výroků platí pro vás a vaše dítě.

\begin{tabular}{|c|c|c|c|c|c|c|c|}
\hline \multirow{2}{*}{$\begin{array}{l}\text { Item } \\
\text { Code }\end{array}$} & \multirow{2}{*}{$\begin{array}{c}\text { Subscale } \\
\text { AM }\end{array}$} & \multirow{2}{*}{$\begin{array}{c}\text { Item } \\
\begin{array}{c}\text { S dítětem si povídám o tom, kolik času tráví s } \\
\text { obrazovkami. }\end{array}\end{array}$} & \multicolumn{5}{|c|}{ Response $^{1}$} \\
\hline & & & 1 & 2 & 3 & 4 & 5 \\
\hline MP2 & $\mathrm{AM}$ & $\begin{array}{c}\text { Dítě vidí, že dokážu kontrolovat dobu, kterou } \\
\text { strávím s obrazovkami. }\end{array}$ & 1 & 2 & 3 & 4 & 5 \\
\hline MP3 & $\mathrm{AM}$ & $\begin{array}{l}\text { Dítěti vysvětluji, jaký obsah je pro něj vhodný } \\
\text { (např. jaká videa, jaké hry, jaké aplikace, jaké } \\
\text { webové stránky, jaké články a obrázky). }\end{array}$ & 1 & 2 & 3 & 4 & 5 \\
\hline MP4 & $\mathrm{AM}$ & $\begin{array}{l}\text { Dítěti pomáhám vyhledávat vhodný obsah } \\
\text { (např. videa, hry, aplikace, webové stránky, } \\
\text { články a obrázky). }\end{array}$ & 1 & 2 & 3 & 4 & 5 \\
\hline MP5 & $\mathrm{OP}$ & $\begin{array}{l}\text { Tajně kontroluji, co a kdy dítě na obrazovce } \\
\text { sledovalo nebo jaké aplikace používalo. }\end{array}$ & 1 & 2 & 3 & 4 & 5 \\
\hline MP6 & $\mathrm{AM}$ & $\begin{array}{l}\text { Před dítětem konzumuji pouze takový obsah } \\
\text { (např. videa, hry, aplikace, webové stránky, } \\
\text { články a obrázky), který je pro něj/ni vhodný. }\end{array}$ & 1 & 2 & 3 & 4 & 5 \\
\hline MP7 & $\mathrm{AM}$ & $\begin{array}{l}\text { S dítětem si povídám o tom, jakým způsobem } \\
\text { použivá obrazovky (např. před spaním, při } \\
\text { učení, při jídle...). }\end{array}$ & 1 & 2 & 3 & 4 & 5 \\
\hline MP8 & $\mathrm{AM}$ & $\begin{array}{l}\text { Dítěti vysvětluji, ve kterých situacích použivání } \\
\text { obrazovek je a není vhodné. }\end{array}$ & 1 & 2 & 3 & 4 & 5 \\
\hline MP9 & $\mathrm{AM}$ & $\begin{array}{l}\text { Dítěti pomáhám najít vhodné situace, ve } \\
\text { kterých může používat obrazovky. }\end{array}$ & 1 & 2 & 3 & 4 & 5 \\
\hline MP10 & OP & $\begin{array}{l}\text { Dítěti dávám najevo, že používat obrazovky je } \\
\text { podle mě ztráta času. }\end{array}$ & 1 & 2 & 3 & 4 & 5 \\
\hline MP11 & $\mathrm{RM}$ & $\begin{array}{l}\text { Máme dohodnutá pravidla, kolik času dítě } \\
\text { stráví s obrazovkami. }\end{array}$ & 1 & 2 & 3 & 4 & 5 \\
\hline MP12 & $\mathrm{RM}$ & $\begin{array}{l}\text { Nenechám dítě s obrazovkou déle, než máme } \\
\text { dohodnuto. }\end{array}$ & 1 & 2 & 3 & 4 & 5 \\
\hline MP13 & $\mathrm{RM}$ & $\begin{array}{l}\text { Všímám si toho, co dítě prostřednictvím } \\
\text { obrazovky konzumuje (např. na jaká videa se } \\
\text { dívá, jaké hry hraje, jaké aplikace používá, jaké } \\
\text { články a obrázky). }\end{array}$ & 1 & 2 & 3 & 4 & 5 \\
\hline
\end{tabular}


Table A5. Cont.

\begin{tabular}{|c|c|c|c|c|c|c|c|}
\hline $\begin{array}{l}\text { Item } \\
\text { Code }\end{array}$ & Subscale & Item & \multicolumn{5}{|c|}{ Response $^{1}$} \\
\hline MP14 & $\mathrm{RM}$ & $\begin{array}{l}\text { Máme dohodnutá pravidla, čemu se dítě na } \\
\text { obrazovce smí a nesmí věnovat (kterým hrám, } \\
\text { videím, aplikacím, textům, obrázkům...). }\end{array}$ & 1 & 2 & 3 & 4 & 5 \\
\hline MP15 & OP & $\begin{array}{l}\text { Neustále kontroluji, čemu se dítě na obrazovce } \\
\text { věnuje. }\end{array}$ & 1 & 2 & 3 & 4 & 5 \\
\hline MP16 & $\mathrm{RM}$ & $\begin{array}{l}\text { Nenechám dítě konzumovat jiný obsah než ten, } \\
\text { na kterém jsme se domluvili. }\end{array}$ & 1 & 2 & 3 & 4 & 5 \\
\hline MP17 & RM & $\begin{array}{l}\text { Všímám si, v jakých situacích dítě sleduje a } \\
\text { použivá obrazovky. }\end{array}$ & 1 & 2 & 3 & 4 & 5 \\
\hline MP18 & $\mathrm{RM}$ & $\begin{array}{l}\text { Máme pravidla, v jakých situacích dítě smí a } \\
\text { nesmí sledovat a používat obrazovky. }\end{array}$ & 1 & 2 & 3 & 4 & 5 \\
\hline MP19 & RM & $\begin{array}{l}\text { Nenechám dítě sledovat nebo používat } \\
\text { obrazovky mimo dohodnuté situace. }\end{array}$ & 1 & 2 & 3 & 4 & 5 \\
\hline MP20 & OP & $\begin{array}{l}\text { Pravidla nastavujeme tak, aby dítě nepoužívalo } \\
\text { obrazovky pro zábavu téměř vůbec. }\end{array}$ & 1 & 2 & 3 & 4 & 5 \\
\hline $\begin{array}{l}\text { IP9. Skór } \\
\text { IP16, MP1 } \\
\text { IP5, MP1 }\end{array}$ & iktivní M & $\begin{array}{l}\text { neplatí), } 3 \text { (tak napůl), } 4 \text { (spíše platí), } 5 \text { (rozhodně platí) } \\
\text { ocčtěte jako prưměr odpovědí na položky MP1, MP2, } \\
\text { diace (RM) vypočtěte jako průměr odpovědí na polož } \\
\text { 9. Skór Hyperprotektivní Mediace (OP) vypočtěte jako } \\
\text {. }\end{array}$ & & & & & $\mathrm{P} 14$ \\
\hline
\end{tabular}

Table A6. MEPA-20: Slovak version.

\begin{tabular}{|c|c|c|c|c|c|c|c|}
\hline \multirow{2}{*}{$\begin{array}{l}\text { Item } \\
\text { Code } \\
\text { MP1 }\end{array}$} & \multirow{2}{*}{$\begin{array}{l}\text { Subscale } \\
\text { AM }\end{array}$} & \multirow{2}{*}{$\begin{array}{c}\text { Item } \\
\begin{array}{c}\text { S diet'at'om sa rozprávam o tom, kol'ko času } \\
\text { tráví s obrazovkami. }\end{array}\end{array}$} & \multicolumn{5}{|c|}{ Response $^{1}$} \\
\hline & & & 1 & 2 & 3 & 4 & 5 \\
\hline MP2 & $\mathrm{AM}$ & $\begin{array}{c}\text { Diet'a vidí, že dokážem kontrolovat' dobu, } \\
\text { ktorú strávim s obrazovkami. }\end{array}$ & 1 & 2 & 3 & 4 & 5 \\
\hline MP3 & $\mathrm{AM}$ & $\begin{array}{l}\text { Diet'at'u vysvetl'ujem, aký obsah je pre neho } \\
\text { vhodný (napr. na aké videá sa pozerá, aké hry } \\
\text { hraje, aké aplikácie použivá, aké webové } \\
\text { stránky, aké články a obrázky). }\end{array}$ & 1 & 2 & 3 & 4 & 5 \\
\hline MP4 & AM & $\begin{array}{l}\text { Diet'at'u pomáham vyhl'adávat' vhodný obsah } \\
\text { (napr. videá, hry, aplikácie, webové stránky, } \\
\text { články a obrázky). }\end{array}$ & 1 & 2 & 3 & 4 & 5 \\
\hline MP5 & $\mathrm{OP}$ & $\begin{array}{l}\text { Tajne kontrolujem, čo a kedy diet'a na } \\
\text { obrazovke sledovalo alebo aké aplikácie } \\
\text { používalo. }\end{array}$ & 1 & 2 & 3 & 4 & 5 \\
\hline MP6 & $\mathrm{AM}$ & $\begin{array}{l}\text { Pred diet'at'om konzumujem iba taký obsah } \\
\text { (napr. videá, hry, aplikácie, webové stránky, } \\
\text { články a obrázky), ktorý je pre neho vhodný. }\end{array}$ & 1 & 2 & 3 & 4 & 5 \\
\hline MP7 & $\mathrm{AM}$ & $\begin{array}{l}\text { S diet'at'om sa rozprávame o tom, akým } \\
\text { spôsobom používa obrazovky (napr. pred } \\
\text { spaním, pri učení, pri jedle...). }\end{array}$ & 1 & 2 & 3 & 4 & 5 \\
\hline MP8 & $\mathrm{AM}$ & $\begin{array}{l}\text { Diet'at'u vysvetl'ujem, v ktorých situáciách je } \\
\text { používanie obrazoviek vhodné a v ktorých nie. }\end{array}$ & 1 & 2 & 3 & 4 & 5 \\
\hline MP9 & $\mathrm{AM}$ & $\begin{array}{l}\text { Diet'at'u pomáham nájst' vhodné situácie, v } \\
\text { ktorých môže používat' obrazovky. }\end{array}$ & 1 & 2 & 3 & 4 & 5 \\
\hline
\end{tabular}


Table A6. Cont.

\begin{tabular}{|c|c|c|c|c|c|c|c|}
\hline \multirow{2}{*}{$\begin{array}{l}\text { Item } \\
\text { Code } \\
\text { MP10 }\end{array}$} & \multirow{2}{*}{$\begin{array}{c}\text { Subscale } \\
\text { OP }\end{array}$} & \multirow{2}{*}{$\begin{array}{c}\text { Item } \\
\begin{array}{c}\text { Diet'at'u dávam najavo, že používat' obrazovky } \\
\text { je podl'a mňa strata času. }\end{array}\end{array}$} & \multicolumn{5}{|c|}{ Response $^{1}$} \\
\hline & & & 1 & 2 & 3 & 4 & 5 \\
\hline MP11 & $\mathrm{RM}$ & $\begin{array}{l}\text { Máme dohodnuté pravidlá, kol'ko času má } \\
\text { diet'a strávít's obrazovkami. }\end{array}$ & 1 & 2 & 3 & 4 & 5 \\
\hline MP12 & $\mathrm{RM}$ & $\begin{array}{l}\text { Nenechám diet'a s obrazovkou dlhšie, než } \\
\text { máme dohodnuté. }\end{array}$ & 1 & 2 & 3 & 4 & 5 \\
\hline MP13 & $\mathrm{RM}$ & $\begin{array}{l}\text { Všímám si to, čo diet’a prostredníctvom } \\
\text { obrazovky konzumuje (napr. na aké videá sa } \\
\text { pozerá, aké hry hrá, aké aplikácie použiva, aké } \\
\text { články a obrázky). }\end{array}$ & 1 & 2 & 3 & 4 & 5 \\
\hline MP14 & $\mathrm{RM}$ & $\begin{array}{l}\text { Máme dohodnuté pravidlá, čomu sa diet'a na } \\
\text { obrazovke smie a nesmie venovat' (ktorým } \\
\text { hrám, videám, aplikáciám, textom, obrázkom...). }\end{array}$ & 1 & 2 & 3 & 4 & 5 \\
\hline MP15 & OP & $\begin{array}{l}\text { Neustále kontrolujem, čomu sa diet'a na } \\
\text { obrazovke venuje. }\end{array}$ & 1 & 2 & 3 & 4 & 5 \\
\hline MP16 & $\mathrm{RM}$ & $\begin{array}{l}\text { Nenechám diet'a konzumovat' iný obsah než } \\
\text { ten, na ktorom sme sa dohodli. }\end{array}$ & 1 & 2 & 3 & 4 & 5 \\
\hline MP17 & $\mathrm{RM}$ & $\begin{array}{l}\text { Všímám si, v ktorých situáciách diet’a sleduje a } \\
\text { používa obrazovky. }\end{array}$ & 1 & 2 & 3 & 4 & 5 \\
\hline MP18 & $\mathrm{RM}$ & $\begin{array}{c}\text { Máme pravidlá, v akých situáciách diet’a smie a } \\
\text { nesmie sledovat' a používat'obrazovky. }\end{array}$ & 1 & 2 & 3 & 4 & 5 \\
\hline MP19 & $\mathrm{RM}$ & $\begin{array}{l}\text { Nenechám diet'a sledovat' alebo používat' } \\
\text { obrazovky mimo dohodnuté situácie. }\end{array}$ & 1 & 2 & 3 & 4 & 5 \\
\hline MP20 & OP & $\begin{array}{c}\text { Pravidlá nastavujeme tak, aby diet'a } \\
\text { nepoužívalo obrazovky pre zábavu takmer } \\
\text { vôbec. }\end{array}$ & 1 & 2 & 3 & 4 & 5 \\
\hline
\end{tabular}

${ }_{1}^{1} 1$ (vôbec neplatí), 2 (skôr neplatí) 3 (tak z polovice), 4 (skôr platí), 5 (rozhodne platí). Inštrukcie pre skórovanie: Skóre Aktívna Mediácia (AM) vypočítame ako priemer odpovedí na položky MP1, MP2, MP3, MP4, MP6, MP7, MP8, a MP9. Skóre Reštriktívna Mediácia (RM) vypočítame ako priemer odpovedí na položky MP11, MP12, MP13, MP14, MP16, MP17, MP18, a MP19. Skóre Hyperprotektívna Mediácia (OP) vypočítame ako priemer odpovedí na položky MP5, MP10, MP15, a MP20.

\section{References}

1. Coyne, S.M.; Radesky, J.; Collier, K.M.; Gentile, D.A.; Linder, J.R.; Nathanson, A.I.; Rasmussen, E.E.; Reich, S.M.; Rogers, J. Parenting and Digital Media. Pediatrics 2017, 140, S112-S116. [CrossRef]

2. Jackson, D.M.; Djafarian, K.; Stewart, J.; Speakman, J.R. Increased television viewing is associated with elevated body fatness but not with lower total energy expenditure in children. Am. J. Clin. Nutr. 2009, 89, 1031-1036. [CrossRef]

3. Hale, L.; Guan, S. Screen time and sleep among school-aged children and adolescents: A systematic literature review. Sleep Med. Rev. 2015, 21, 50-58. [CrossRef]

4. Pagani, L.S.; Harbec, M.J.; Barnett, T.A. Prospective associations between television in the preschool bedroom and later biopsycho-social risks. Pediatr. Res. 2019, 85, 967-973. [CrossRef]

5. Christakis, D.A.; Zimmerman, F.J.; DiGiuseppe, D.L.; McCarty, C.A. Early Television Exposure and Subsequent Attentional Problems in Children. Pediatrics 2004, 113, 708-713. [CrossRef]

6. Council on communications and media. Media Use in School-Aged Children and Adolescents. Pediatrics 2016, 138, e20162592. [CrossRef] [PubMed]

7. Livingstone, S.; Helsper, E.J. Parental Mediation of Children's Internet Use. J. Broadcasting Electron. Media 2008, 52, 581-599. [CrossRef]

8. González-Cámara, M.; Osorio, A.; Reparaz, C. Measurement and Function of the Control Dimension in Parenting Styles: A Systematic Review. IJERPH 2019, 16, 3157. [CrossRef]

9. Lukavská, K.; Vacek, J.; Gabhelík, R. The effects of parental control and warmth on problematic internet use in adolescents: A prospective cohort study. JBA 2020, 9, 664-675. [CrossRef] [PubMed] 
10. Petruzelka, B.; Vacek, J.; Gavurova, B.; Kubak, M.; Gabrhelik, R.; Rogalewicz, V.; Bartak, M. Interaction of Socioeconomic Status with Risky Internet Use, Gambling and Substance Use in Adolescents from a Structurally Disadvantaged Region in Central Europe. IJERPH 2020, 17, 4803. [CrossRef] [PubMed]

11. Collier, K.M.; Coyne, S.M.; Rasmussen, E.E.; Hawkins, A.J.; Padilla-Walker, L.M.; Erickson, S.E.; Memmott-Elison, M.K. Does parental mediation of media influence child outcomes? A meta-analysis on media time, aggression, substance use, and sexual behavior. Dev. Psychol. 2016, 52, 798-812. [CrossRef]

12. Elsaesser, C.; Russell, B.; Ohannessian, C.M.; Patton, D. Parenting in a digital age: A review of parents' role in preventing adolescent cyberbullying. Aggress. Violent Behav. 2017, 35, 62-72. [CrossRef]

13. Nielsen, P.; Favez, N.; Liddle, H.; Rigter, H. Linking parental mediation practices to adolescents' problematic online screen use: A systematic literature review. J. Behav. Addict. 2019, 8, 649-663. [CrossRef]

14. Austin, E.W. Exploring the effects of active parental mediation of television content. J. Broadcasting Electron. Media 1993, 37, 147-158. [CrossRef]

15. Koning, I.M.; Peeters, M.; Finkenauer, C.; Van Den Eijnden, R.J. Bidirectional effects of Internet-specific parenting practices and compulsive social media and Internet game use. J. Behav. Addict. 2018, 7, 624-632. [CrossRef]

16. Kalmus, V.; Blinka, L.; Ólafsson, K. Does It Matter What Mama Says: Evaluating the Role of Parental Mediation in European Adolescents' Excessive Internet Use. Child Soc. 2015, 29, 122-133. [CrossRef]

17. Domoff, S.E.; Radesky, J.S.; Harrison, K.; Riley, H.; Lumeng, J.C.; Miller, A.L. A Naturalistic Study of Child and Family Screen Media and Mobile Device Use. J. Child Fam. Stud. 2019, 28, 401-410. [CrossRef] [PubMed]

18. Vacek, J.; Vonkova, H.; Gabrhelík, R. A Successful Strategy for Linking Anonymous Data from Students' and Parents' Questionnaires Using Self-Generated Identification Codes. Prev. Sci. 2017, 18, 450-458. [CrossRef]

19. Livingstone, S.; Haddon, L.; Görzig, A.; Ólafsson, K. Risks and Safety on the Internet: The Perspective of European Children: Full Findings and Policy Implications from the EU Kids Online Survey of 9-16 Year Olds and Their Parents in 25 Countries; EU Kids Online: London, UK, 2011; ISSN 2045-256X.

20. Van den Bulck, J.; Van den Bergh, B. The Influence of Perceived Parental Guidance Patterns on Children's Media Use: Gender Differences and Media Displacement. J. Broadcasting Electron. Media 2000, 44, 329-348. [CrossRef]

21. Bumpus, M.F.; Werner, N.E. Maternal Rule-Setting for Children's Internet Use. Marriage Fam. Rev. 2009, 45, 845-865. [CrossRef]

22. Stattin, H.; Kerr, M. Parental Monitoring: A Reinterpretation. Child Dev. 2000, 71, 1072-1085. [CrossRef] [PubMed]

23. Valkenburg, P.M.; Piotrowski, J.T.; Hermanns, J.; De Leeuw, R. Developing and Validating the Perceived Parental Media Mediation Scale: A Self-Determination Perspective: Parental Mediation Scale. Hum. Commun. Res. 2013, 39, 445-469. [CrossRef]

24. Van den Eijnden, R.J.J.M.; Spijkerman, R.; Vermulst, A.A.; van Rooij, T.J.; Engels, R.C. Compulsive Internet Use Among Adolescents: Bidirectional Parent-Child Relationships. J. Abnorm. Child Psychol. 2010, 38, 77-89. [CrossRef] [PubMed]

25. Guttman, R.; Greenbaum, C.W. Facet Theory. Eur. Psychol. 1998, 3, 13-36. [CrossRef]

26. Cetinkaya, L. The Relationship between Perceived Parental Control and Internet Addiction: A Cross-sectional study among Adolescents. Contemp. Educ. Technol. 2019, 10, 55-74. [CrossRef]

27. Carter, B.; Rees, P.; Hale, L.; Bhattacharjee, D.; Paradkar, M.S. Association Between Portable Screen-Based Media Device Access or Use and Sleep Outcomes: A Systematic Review and Meta-analysis. JAMA Pediatr. 2016, 170, 1202. [CrossRef]

28. Jago, R.; Baranowski, T.; Baranowski, J.C.; Thompson, D.; Greaves, K.A. BMI from 3-6 y of age is predicted by TV viewing and physical activity, not diet. Int. J. Obes. 2005, 29, 557-564. [CrossRef]

29. Kirkorian, H.L.; Pempek, T.A.; Murphy, L.A.; Schmidt, M.E.; Anderson, D.R. The Impact of Background Television on Parent-Child Interaction. Child Dev. 2009, 80, 1350-1359. [CrossRef]

30. Radesky, J.S.; Peacock-Chambers, E.; Zuckerman, B.; Silverstein, M. Use of Mobile Technology to Calm Upset Children: Associations with Social-Emotional Development. JAMA Pediatr. 2016, 170, 397. [CrossRef]

31. Schmidt, M.E.; Pempek, T.A.; Kirkorian, H.L.; Lund, A.F.; Anderson, D.R. The Effects of Background Television on the Toy Play Behavior of Very Young Children. Child Dev. 2008, 79, 1137-1151. [CrossRef]

32. Uncapher, M.R.; Lin, L.; Rosen, L.D.; Kirkorian, H.L.; Baron, N.S.; Bailey, K.; Cantor, J.; Strayer, D.L.; Parsons, T.D.; Wagner, A.D. Media Multitasking and Cognitive, Psychological, Neural, and Learning Differences. Pediatrics 2017, 140, S62-S66. [CrossRef] [PubMed]

33. Hooper, D.; Coughlan, J.; Mullen, M.R. Structural Equation Modelling: Guidelines for Determining Model Fit. Electron. J. Bus. Res. Methods 2008, 6, 53-60.

34. Miovský, M.; Voňková, H.; Gabrhelík, R.; Št'astná, L. Universality Properties of School-Based Preventive Intervention Targeted at Cannabis Use. Prev. Sci. 2015, 16, 189-199. [CrossRef] [PubMed]

35. Miovský, M.; Vonkova, H.; Čablová, L.; Gabrhelík, R. Cannabis use in children with individualized risk profiles: Predicting the effect of universal prevention intervention. Addict. Behav. 2015, 50, 110-116. [CrossRef] [PubMed]

36. Gabrhelik, R.; Duncan, A.; Miovsky, M.; Furr-Holden, C.D.M.; Stastna, L.; Jurystova, L. “Unplugged”: A school-based randomized control trial to prevent and reduce adolescent substance use in the Czech Republic. Drug Alcohol. Depend. 2012, $124,79-87$. [CrossRef]

37. Vondráčková, P.; Gabrhelík, R. Prevention of Internet addiction: A systematic review. J. Behav. Addict. 2016, 5, 568-579. [CrossRef]

38. Lukavská, K.; Burda, V.; Lukavský, J.; Slussareff, M.; Gabrhelík, R. School-Based Prevention of Screen-Related Risk Behaviors during the Long-Term Distant Schooling Caused by COVID-19 Outbreak. IJERPH 2021, 18, 8561. [CrossRef] 